\title{
A CERÂMICA GRAFITADA E O SEU CONTEXTO, ENTRE A MARGEM ESQUERda do GuAdiana E A SERRA dE ARACENA
}

Graphite coated pottery and its context, between the Guadiana left bank and the Sierra de Aracena

RUi SOARES FCT. UNIARQ - Centro de Arqueologia da Universidade de Lisboa

Recibido: 21/03/2017

Revisado: 25/04/2017
Aceptado: $19 / 05 / 2017$

Publicado: 23/06/2017

\section{RESUMO}

Durante os séculos V e IV a.C., ao longo da bacia hidrográfica do rio Ardila, entre a margem esquerda do Guadiana e a Serra de Aracena, a decoração de determinados recipientes cerâmicos com recurso à aplicação de grafite foi uma realidade detectada em algumas ocupações sidéricas conhecidas, nomeadamente, no Cabeço Redondo, na Azougada, no Castelo Velho de Safara e em El Castañuelo. As temáticas decorativas e a tipologia dos recipientes decorados com grafite variam entre os sítios, pelo que esta análise permite classificar os recipientes cerâmicos consoante as diferentes formas e temas decorativos detectados. A compartimentação tipológica e a análise articulada da cultura material dos sítios onde até agora se detectou este tipo decorativo, permite tecer considerações sobre a importância dos recipientes grafitados e a sua pertinência para uma análise cronológica dos sítios arqueológicos onde ocorrem ou onde podem vir a ser identificados no futuro.

\section{Palavras Chave}

Cerâmica grafitada; Grafite; Idade do Ferro; Margem esquerda do Guadiana; Rio Ardila.
ABSTRACT

During the 5th and 4th centuries BC, along the Ardila basin, between the Guadiana left bank and the Sierra de Aracena, the pottery decoration using the application of graphite in the surface of some containers was a reality found in some known Iron Age sites, namely in Cabeço Redondo, Castro da Azougada, Castelo Velho de Safara and El Castañuelo. The decorative themes and the typology of these containers vary between sites, which can form the basis of a classification of this ceramic. A detailed typological study of the material culture found in the places where this decoration has been found allows to discuss its importance and relevance for a chronological analysis of archaeological sites where it is found or where it could be identified in the future.

\section{KEY WORDS}

Graphite coated pottery; Iron Age; Left bank of the Guadiana River; Ardila River

ruigusmao@hotmail.com 


\section{INTRODUÇÃO}

O presente artigo analisa a cerâmica decorada com aplicação de grafite (cerâmica grafitada) do território compreendido entre a margem esquerda portuguesa do Guadiana e a serra de Aracena, em Espanha. Inicialmente esta análise começou por resultar da investigação produzida sobre o sítio do Cabeço Redondo, para obtenção do grau de Mestre em Arqueologia em 2012, na Universidade de Lisboa (Soares, 2012). O interesse das cerâmicas grafitadas recolhidas na escavação do Cabeço Redondo, conduziu à necessidade de continuar a sua investigação após a conclusão do mestrado, facto que me levou a aprofundar o seu estudo no trabalho apresentado em Novembro de 2013 ao VII Encontro de Arqueologia do Sudoeste Peninsular, no qual se procurava analisar as cerâmicas grafitadas do Cabeço Redondo, em articulação com os conjuntos da Azougada, do Castelo Velho de Safara e do até agora único recipiente grafitado publicado proveniente de El Castañuelo.

A apresentação pública destes resultados resultou no desafio efectuado pelo professor Doutor Juan Aurélio Pérez Macías ainda durante esse congresso, para que eu procedesse ao estudo de El Castañuelo, o qual possuia vários recipientes grafitados ainda inéditos e uma cultura material extraordinariamente semelhante ao sítio do Cabeço Redondo. Decorrida uma primeira visita ao Museo de Huelva onde se encontram depositados os materiais de Castañuelo, tornou-se claro que não faria sentido publicar o artigo inicialmente por mim pensado nas actas do VII Encontro do Sudoeste, sem estudar e incluir os materiais inéditos de Castañuelo, sob pena de desperdiçar um importante conjunto de informações, dada a já referida importante semelhança com os materiais do Cabeço Redondo. Iniciei então o estudo deste sítio em Fevereiro de 2014, tendo concluído o mesmo ainda em Dezembro desse mesmo ano, após três intensas campanhas de trabalho nos depósitos do Museo de Huelva.

Posteriormente, tendo iniciado uma bolsa de doutoramento em Outubro de 2016 financiada pela Fundação para a Ciência e Tecnologia, com o objectivo de estudar a Idade do Ferro precisamente no território aqui mencionado, foi me possível finalmente concluir o tratamento dos dados extraídos do estudo de El Castañuelo, bem como efectuar uma revisão dos materiais cerâmicos do Castro da Azougada já antes publicados por outro autor (Antunes, 2005 e 2009), facto que permitiu que aqui apresentemos a correcção de várias peças grafitadas desse estudo.

$\mathrm{O}$ artigo aqui apresentado é portanto o resultado do estudo que tenho vindo a desenvolver sobre esta importante temática, no âmbito do meu doutoramento.

A CERÂMICA GRAFITADA: ALGUNS CONCEITOS INTRODUTÓRIOS

Sobre a definição do que é a cerâmica grafitada, recordamos alguns autores anteriores que se debruçaram sobre esta questão e que recolhem bibliografia anterior (Barroso Bermejo, 2002; Nájera Marcos, 2009), pelo que por questões de operacionalidade, utilizaremos a definição mais recente, proposta por Nájera Marcos (2009, p. 76), o qual refere que o grafitado é uma técnica decorativa que consiste na aplicação de grafito mineral, ou de uma solução composta por ele, à superficie de um objecto.

No caso dos recipientes cerâmicos, esta decoração pode aplicar-se a uma ou a ambas as superficies da peça (interior e exterior), quer seja simplesmente cobrindo-as total ou parcialmente, quer seja criando motivos decorativos variados. Os métodos de aplicação são também variados (Nájera Marcos, 2009 , p. 84), sendo possível aplicar a grafite durante o processo de secagem da peça, imediatamente antes da cozedura, ou então, após a cozedura.

Quanto à sua origem, esta forma de decoração surgiu no sudeste europeu, na região situada entre os Balcãs e o Mar Negro, durante o Neolítico Recente, tendo posteriormente expandido-se até ao centro da Europa durante o Bronze Final (para uma análise detalhada desta expansão, veja-se Nájera Marcos, 2009, p. 77 e 78). A Península Ibérica esta decoração terá chegado também durante os finais da Idade do Bronze, entrando pelo Norte, na zona do Alto Ebro, após o que se terá expandido para ocidente e para sul, apresentando a sua máxima expressão entre o século VIII e o século V a.C. (Nájera Marcos, 2009, p. 74 e 78), chegando a território hoje português aparentemente apenas durante a Idade do Ferro, no século V a.C., como veremos ao longo desta análise.

A identificação e o estudo arqueológico desta decoração reúne uma série de problemáticas que importa identificar. Em primeiro lugar, a correcta identificação da decoração grafitada não é uma tarefa fácil, dado que em algumas peças, mesmo os investigadores mais habituados a estudar esta decoração, sentem por vezes dificuldades em dizer com 
certeza se o pigmento se encontra presente. Esta dificuldade pode decorrer de várias questões, algumas das quais resultam da minha experiência pessoal, as quais passo a enumerar:

- A decoração conserva-se mal, pelo que facilmente as peças perdem parcial ou totalmente o pigmento, quer seja por utilização antiga, quer seja por condições pós-deposicionais, ou ainda por um excesso de lavagem em laboratório, dificultando ou impedindo a sua identificação;

- Em virtude dos factores anteriores, a decoração por vezes só é perceptível jogando com a orientação da peça e com a incidência da luz na sua superfície. A utilização de uma peça com grafite bem identificada, colocada ao lado de uma peça duvidosa que se quer identificar, por vezes ajuda a perceber se a grafite está presente ou não;

- A decoração é passível de ser confundida com um alisamento ou polimento intenso, ou mesmo até com um brunimento característico de cerâmicas do Bronze Final, sendo também possível a sua confusão com cerâmica cinzenta polida;

- A decoração pode também ser confundida com cerâmicas com presença elevada de micas ou de quartzo moído, ou ainda com cerâmica de cozedura redutora com polimento intenso pós-cozedura (Nájera Marcos, 2009, p. 77);

- Dada a raridade desta decoração, a maioria dos arqueólogos nunca a pôde observar directamente, o que dificulta a sua identificação, dado que é necessário observar vários exemplares, em especial os que apresentam um grafitado bastante gasto, por forma a aprender a reconhecer correctamente o aspecto visual e as características do mesmo.

\section{O TERRITÓRIO}

A zona alvo desta análise localiza-se no sudoeste peninsular, em sítios arqueológicos com presença de cerâmica grafitada localizados em duas zonas administrativas distintas, nomeadamente, em Portugal, com os sítios do Cabeço Redondo, Castro da Azougada e Castelo Velho de Safara implantados na margem esquerda do Guadiana, no Concelho de Moura, ao longo da bacia do rio Ardila; em Espanha, com o sítio de El Castañuelo implantado no Parque $\mathrm{Na-}$ tural da Serra de Aracena e Picos de Aroche, numa zona de influência da Rivera de Huelva, tributária do rio Guadalquivir, mas que fica ainda bastante próximo também da zona de influência dos afluentes do rio Ardila (Fig. 1). Esta área analisada é assim delimitada e estruturada pelos rios Guadiana,
Chança, Ardila e Rivera de Huelva, sendo ainda delimitada naturalmente pelos contrafortes da serra Morena.

Neste território existem portanto quatro sítios com ocupações da Idade do Ferro que possuem cerâmica grafitada, todos localizados na bacia do rio Ardila ou muito próximo desta, nomeadamente a Azougada, que se encontra implantada num cabeço sobranceiro à foz do rio Ardila; o Cabeço Redondo, localizado numa zona de planície atravessada por duas ribeiras, a ribeira de S. Pedro e a ribeira de Toutalga, que são ambas tributários do Ardila, o Castelo Velho Safara, implantado num esporão rochoso sobranceiro ao Ardila, numa zona mais interior em relação ao Guadiana e por fim o sítio da Idade do Ferro de El Castañuelo, em território espanhol. Podemos assim concluir que estes quatro sítios onde até agora se detectou a presença de cerâmicas grafitadas se encontram directa ou indirectamente relacionados com a bacia do rio Ardila.

Para além dos locais enunciados onde se detectaram cerâmicas grafitadas, existem muitos outros sítios da Idade do Ferro na área aqui estudada ou próximo dela, onde até agora não se verificou a presença da decoração com grafite. De forma não exaustiva, podemos referir sítios da I Idade do Ferro, como Torre Velha 3, Salsa 3, Passo Alto, Amendoeira 3, Monte da Lage, Montinhos 6; ou sítios da II Idade do Ferro, como o Castelo de Serpa, o po-

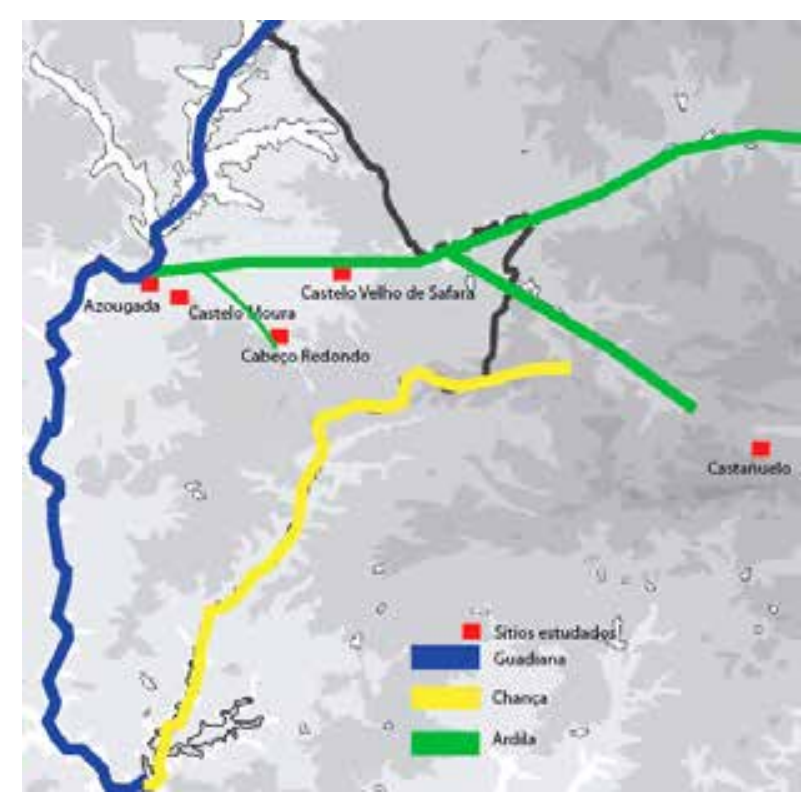

Figura 1 - Território e sítios analisados 
voado da Misericórdia, Castelo de Moura, Castelo de Noudar, Capote, Pasada del Abad entre outros.

Os motivos que explicam a concentração de cerâmicas grafitadas numa cronologia e geografia muito específica e limitada a alguns pouco sítios, encontram-se ainda por desvendar, pelo que passamos em seguida a analisar as particularidades destes sítios e das suas cerâmicas.

\section{O SÉcUlo V A.C.}

Cabeço Redondo

O sítio arqueológico do Cabeço Redondo (Moura), localizado numa zona de planície atravessada por duas ribeiras, S. Pedro e a de Toutalga, ambas tributárias do rio Ardila, foi destruído em grande parte durante trabalhos agrícolas em 1990, tendo sido objecto de escavações arqueológicas em 2011 no âmbito do Mestrado realizado pelo signatário deste artigo (Soares, 2012). As evidências materiais e estratigráficas registadas no Cabeço Redondo (Soares 2012; Soares e Soares no prelo; Cardoso e Soares, 2013; Soares et al. 2013; Valério et al., 2015) obtidas através de artefactos descontextualizados recuperados após a destruição do sítio e durante a realização das escavações arqueológicas (duas sondagens de 24 m x $1 \mathrm{~m}$ ), confirmam a presença de uma ocupação rural e de um espaço edificado construído com muros de base pétrea que se desenvolviam em altura com paredes de tijolos de adobe (Fig. 2), o qual terá

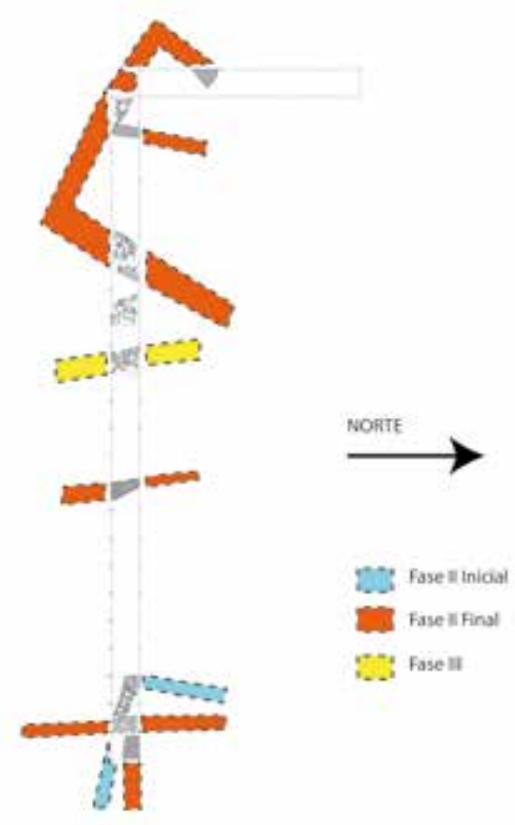

Figura 2 - Arquitectura do Cabeço Redondo sido remodelado ao longo de várias fases construtivas.

A análise dos materiais, dos quais fazem parte numerosas ânforas de produção local (Fig. 5, no 1-4) e escassos materiais importados como cerâmica ática (Fig. 3, nº 9-10), ânforas e cerâmica pintada (Fig. 3, $\mathrm{n}^{\mathrm{o}} 8$ ), comprovam uma cronologia do séc. V a.C., ao mesmo tempo que em conjunto com a arquitectura, confirmam a presença de um edifício monumental e singular na margem esquerda portuguesa do Guadiana, cujo paralelo mais aproximado no Sudoeste peninsular se encontra nos edifícios existentes no Médio Guadiana em Espanha, nomeadamente, em Cancho Roano (Celestino Pérez e Jiménez Ávila 1993; Celestino Pérez 1996) e La Mata (Rodríguez Díaz 2004).

No que diz respeito à cerâmica grafitada, nota-se a presença de peças totalmente grafitadas na superficie exterior, principalmente em recipientes fechados de grande dimensão (Fig. $4, \mathrm{n}^{\mathrm{o}} 1$ a 3), encontrando-se também alguns potes/panelas de média (Fig. 4, no 4) e pequena dimensão (Fig. 4, no 5 e 8) e ainda alguns pequenos recipientes abertos como tigelas, totalmente grafitados tanto por dentro como por fora, como evidenciam alguns fragmentos de fundo (Fig. 4, no 6 e 7).

De notar que um dos grandes recipientes fechados possui três perfurações no bordo (Fig. $4, \mathrm{n}^{\mathrm{o}} 1$ ). De modo igual, note-se que um pote detectado (Fig. $4, \mathrm{n}^{\mathrm{o}} 4$ ) possui indicios da presença de um furo junto ao fundo, idêntico a um pote de El Castañuelo, como veremos mais adiante (Fig. 9, $\mathrm{n}^{\mathrm{0}}$ 6). A sua função parece prender-se com a dispensa de liquidos, à semelhança do que se verifica em outros casos durante a Idade do Ferro (Mataloto, 2004, p. 75 e 76; Langley et al., p.244 e $245, \mathrm{n}^{\mathrm{o}} 4$ ). Este pote fazia parte de um grupo de materiais que se encontraram durante as escavações de 2011, depositados inteiros (ainda que fragmentados) e em conjunto (Fig. 5). As peças, das quais fazem parte ânforas, potes, alguidares e um cossoiro, encontram-se na sua maioria incompletas, pois o resto dos seus fragmentos encontrava-se fora dos limites da sondagem, não tendo sido possível recuperá-los. Este conjunto demonstra o abandono rápido do edifício do Cabeço Redondo, deixando os objectos no local em que se encontravam, sendo que este fenómeno parece ser habitual nas ocupações rurais do sudoeste peninsular durante os finais do século $\mathrm{V}$ a.C., como se observa por exemplo, em Cancho Roano (Celestino e Jiménez Ávila, 1993; Celestino, 1996) e La 

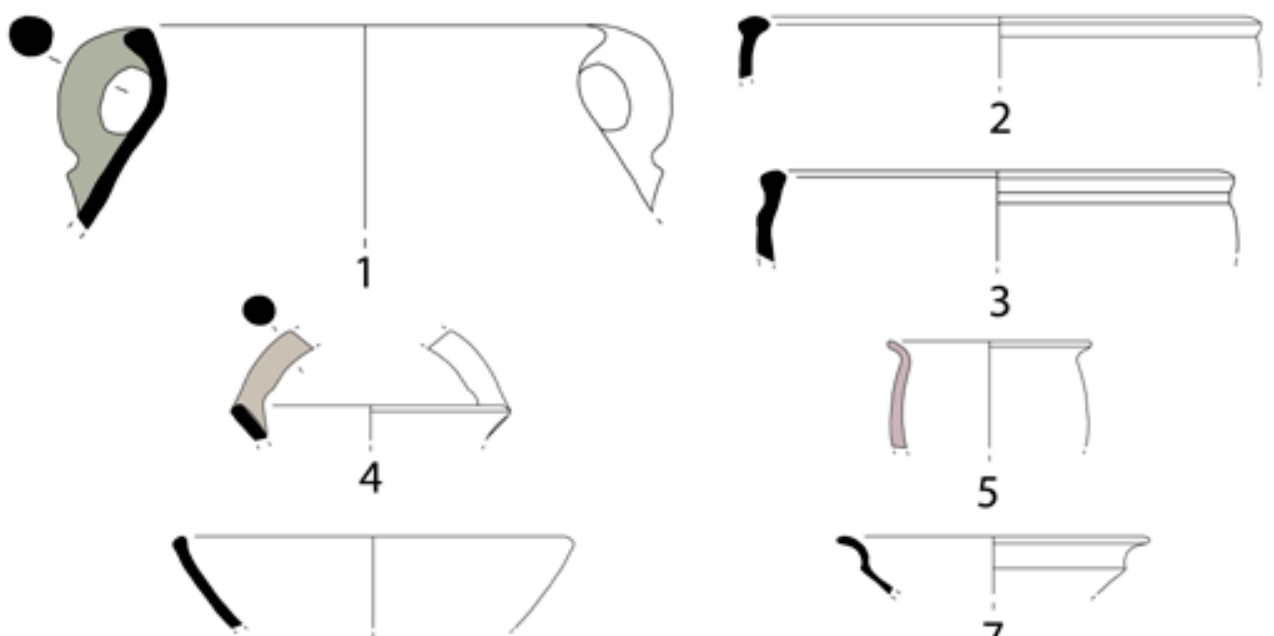

6
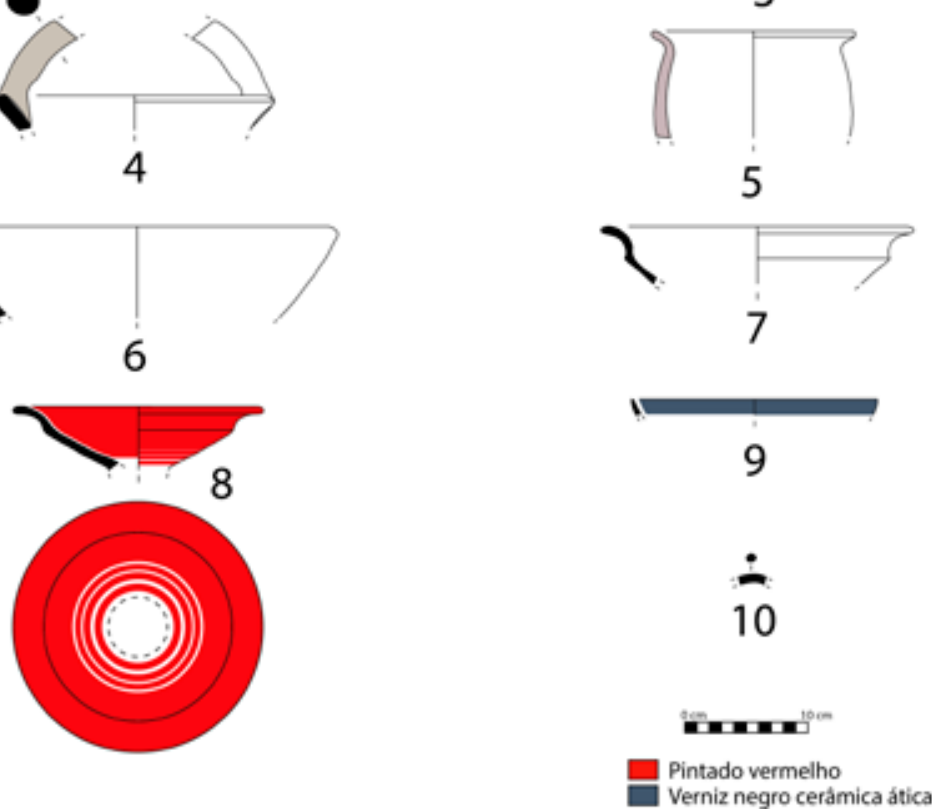

Figura 3 - Materiais do Cabeço Redondo

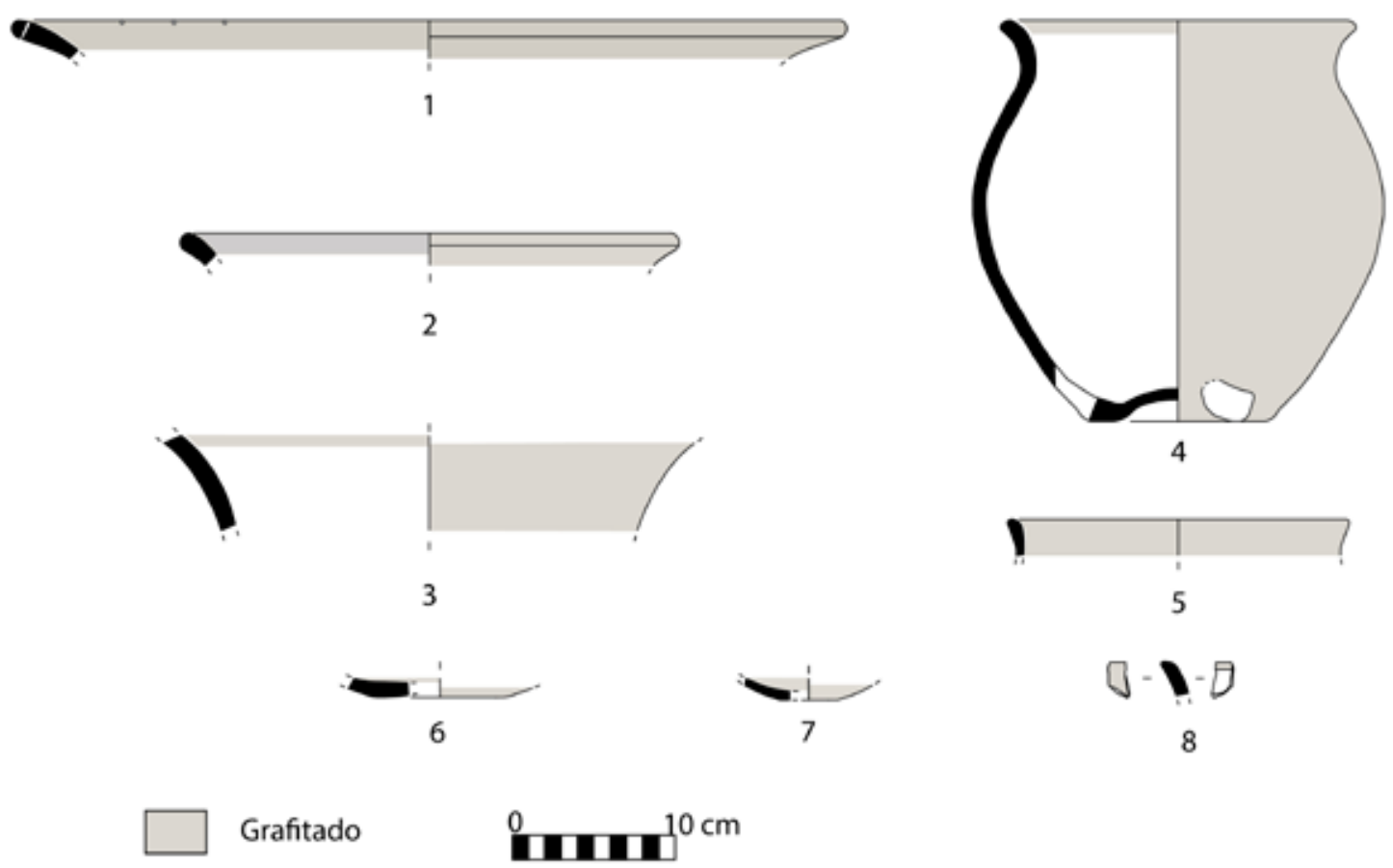

Figura 4 - Cerâmicas grafitadas do Cabeço Redondo 
Mata (Rodríguez Díaz, 2004), ou regionalmente na Azougada (Antunes, 2009) e em El Castañuelo (Amo, 1978).

Uma referência deve ser feita no que diz respeito ao fabrico das peças grafitadas, pois alguns exemplares do Cabeço Redondo aparentam ter sido efectuados num torno lento e alguns bojos em cerâmica manual, correspondendo as formas identificáveis, maioritariamente, a recipientes fechados, de cozeduras exclusivamente redutoras.
A existência de cerâmica completamente grafitada na face externa e, por vezes, na interna, semelhante aos referidos exemplares do Cabeço Redondo, é conhecida na Meseta, no Cerro de Santa Ana, Cerro de Sorban e no Castro do Río Salido, bem como em Cástulo (Ellering, 1987-1988, p. 191; Blázquez Martínez e Valiente Malla, 1980 e 1981) e em El Castañuelo. (Fig. 5).
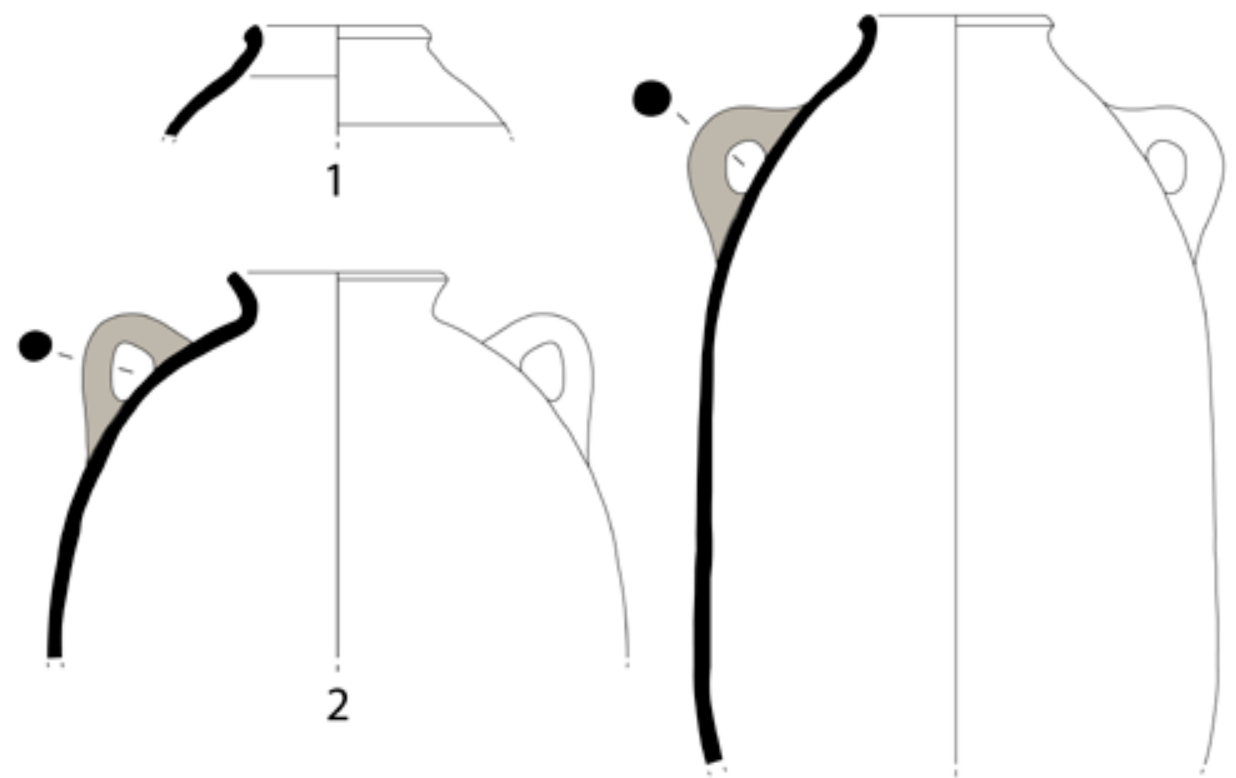

3
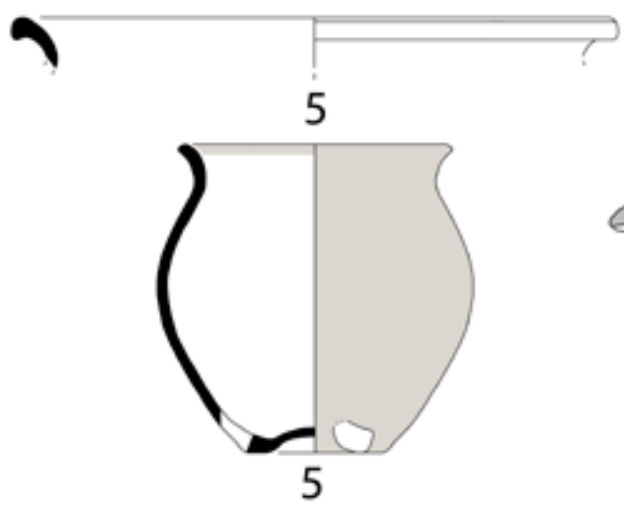

4
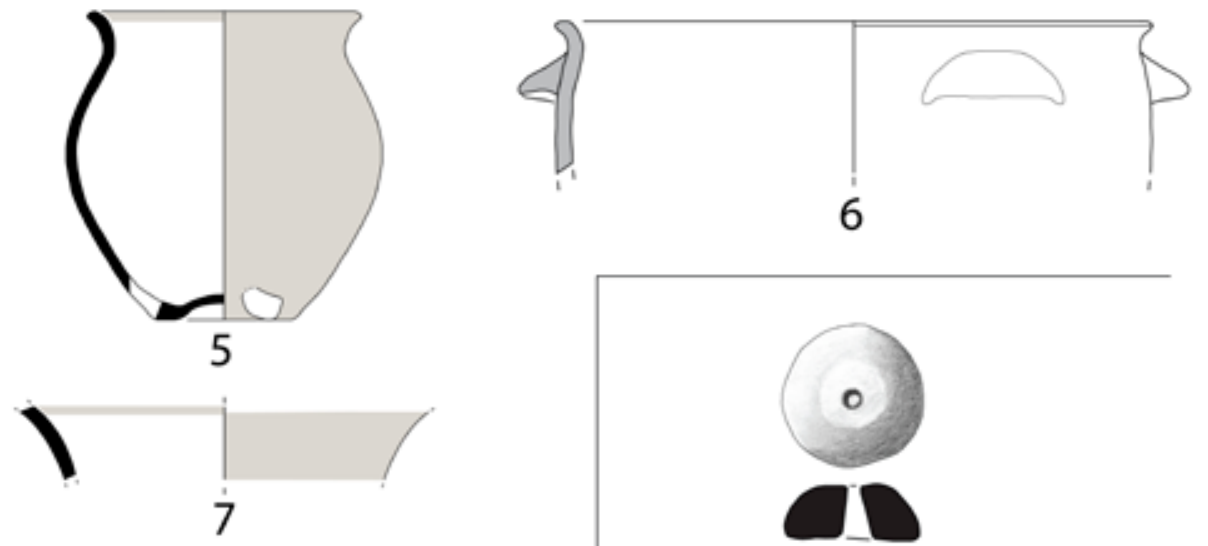

Grafitado
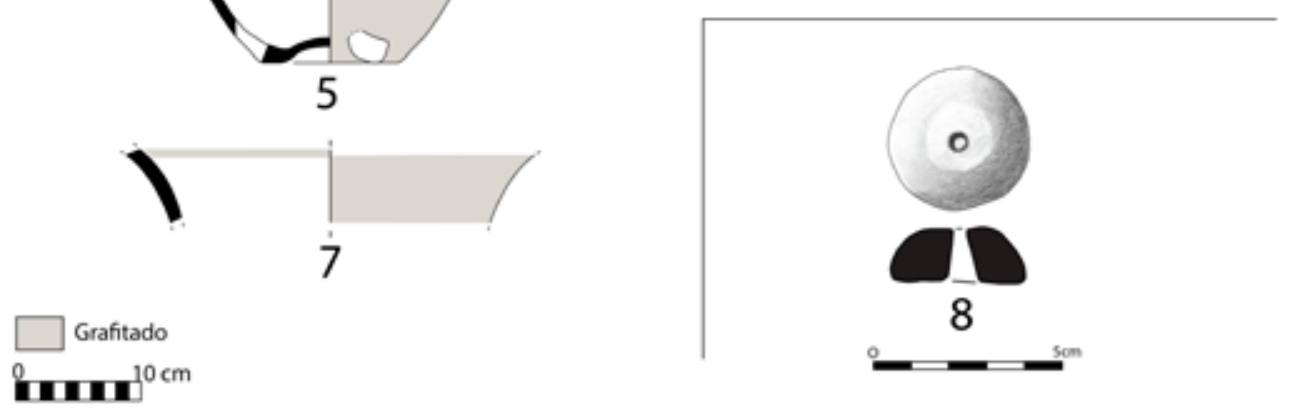

Figura 5 - Materiais do Cabeço Redondo encontrados em conjunto 


\section{El Castañuelo}

Situado em Espanha, em pleno Parque Natural de Serra de Aracena e Picos de Aroche, El Castañuelo corresponde a uma ocupação do século $\mathrm{V}$ a.C. sobreposta a um povoado do Bronze pleno, implantado no alto de um pequeno cabeço sobranceiro ao Barranco de La Nava, o qual é tributário da Rivera de Huelva, por sua vez pertencente à bacia do rio Guadalquivir. $\mathrm{O}$ alto deste cabeço, mais ou menos aplanado, apresenta uma área de cerca de $1 \mathrm{Ha}$, encontrando-se o acesso natural ao sítio do lado Este, uma vez que as vertentes Norte, Oeste e Sul apresentam uma pendente significativa (Fig. 6) .

Este povoado foi inicialmente descoberto por Mariano del Amo (1978). As escavações efectuadas por este na década de 70, centraram-se na zona Este do sítio, precisamente no local onde desemboca o seu acesso natural, procurando encontrar o habitat correspondente às cistas da Idade do Bronze que rodeiam o cabeço. A metodologia empregue pelo escavador passou pela abertura na zona Este, de nove quadrículas de quatro metros de lado separadas por testemunhos, resultando numa área escavada de cerca de $200 \mathrm{~m} 2$. No entanto, após o início dos trabalhos rapidamente Mariano del Amo se apercebeu que por cima do povoado da Idade do Bronze que procurava, se encontrava um povoado da Idade do Ferro, composto por construções ortogonais de base pétrea, das quais os seus escavadores individualizaram cerca de onze ou doze pequenos espaços ou compartimentos (Fig. 7).

No que diz respeito aos materiais arqueológicos, alguns deles já publicados (Pérez Macias, 1991; Pérez Macías e Gómez Toscano, 1999; Jiménez Ávila, 2009; Fernández Jurado e Cabrera Bonet, 1989), estes eram compostos por alguns metais, líticos, cossoiros e sobretudo por um vasto conjunto de recipientes cerâmicos, os quais se encontraram na sua maioria completos, mas fragmentados in situ sobre o pavimento dos vários compartimentos identificados. Entre estes recipientes destacam-se, pelo seu valor cronológico que indica uma ocupação do século $\mathrm{V}$ a.C., alguns fragmentos de taças cástulo (Fig. $8, n^{\circ} 12$ e 13), um fragmento de bordo e asa de um skyphos de bordo recto (Fig. 8, no 14 ), bem como um numeroso conjunto de ânforas importadas, nomeadamente, ânforas Maña Pascual A4 (Fig. 8, n 1), bem como ânforas a torno de produção local/ regional (Fig. 8, n⿳0 3), ânforas de cerâmica manual, as quais imitam os modelos produzidos a torno (Fig. 8, $\mathrm{n}^{\circ} 4$ e 6) e ânforas miniaturizadas de cerâmica manual, as quais imitam os modelos de dimensão normal (Fig. 8, nº 2 e 5).

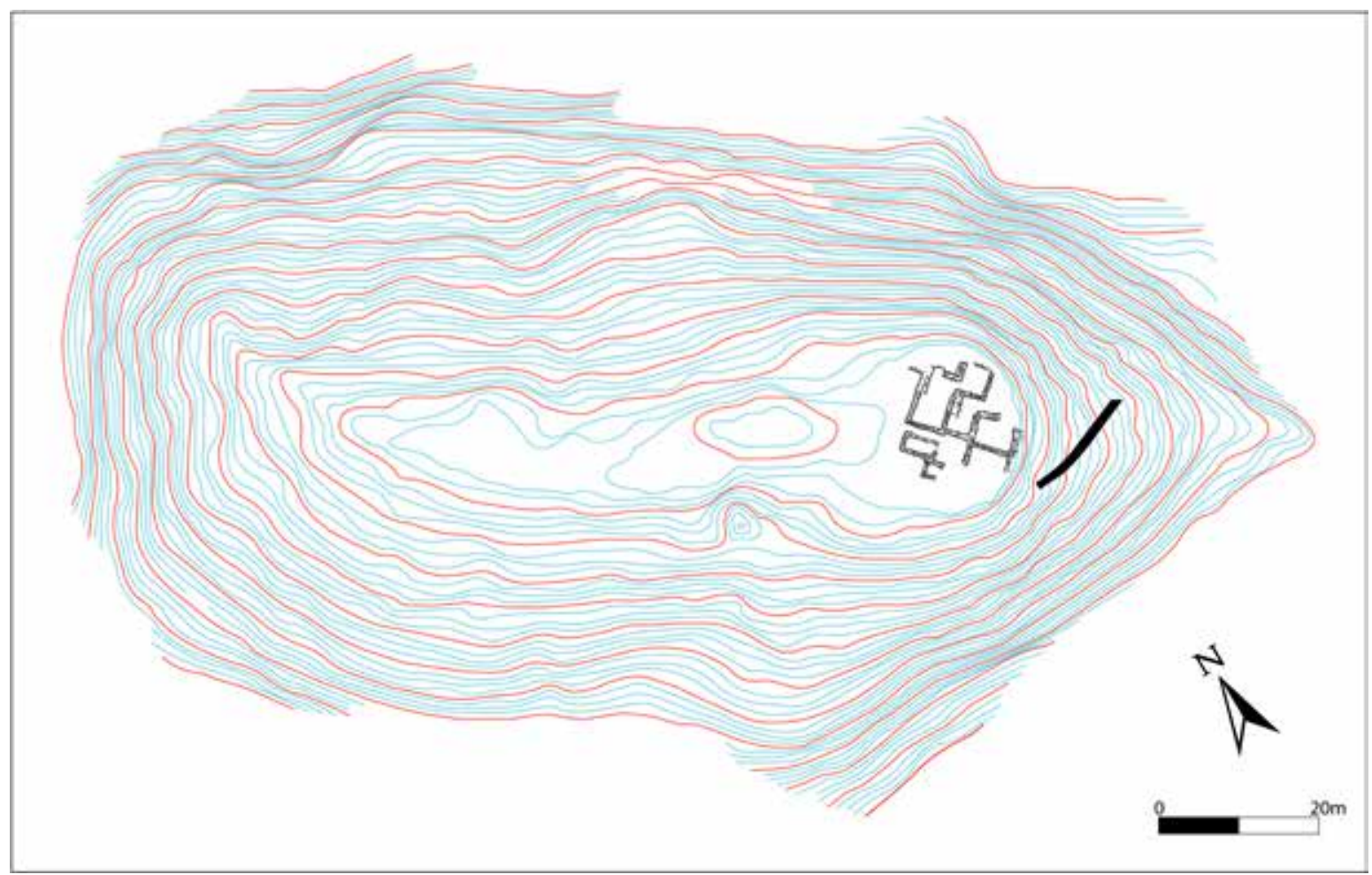

Figura 6 - Implantação Castañuelo 


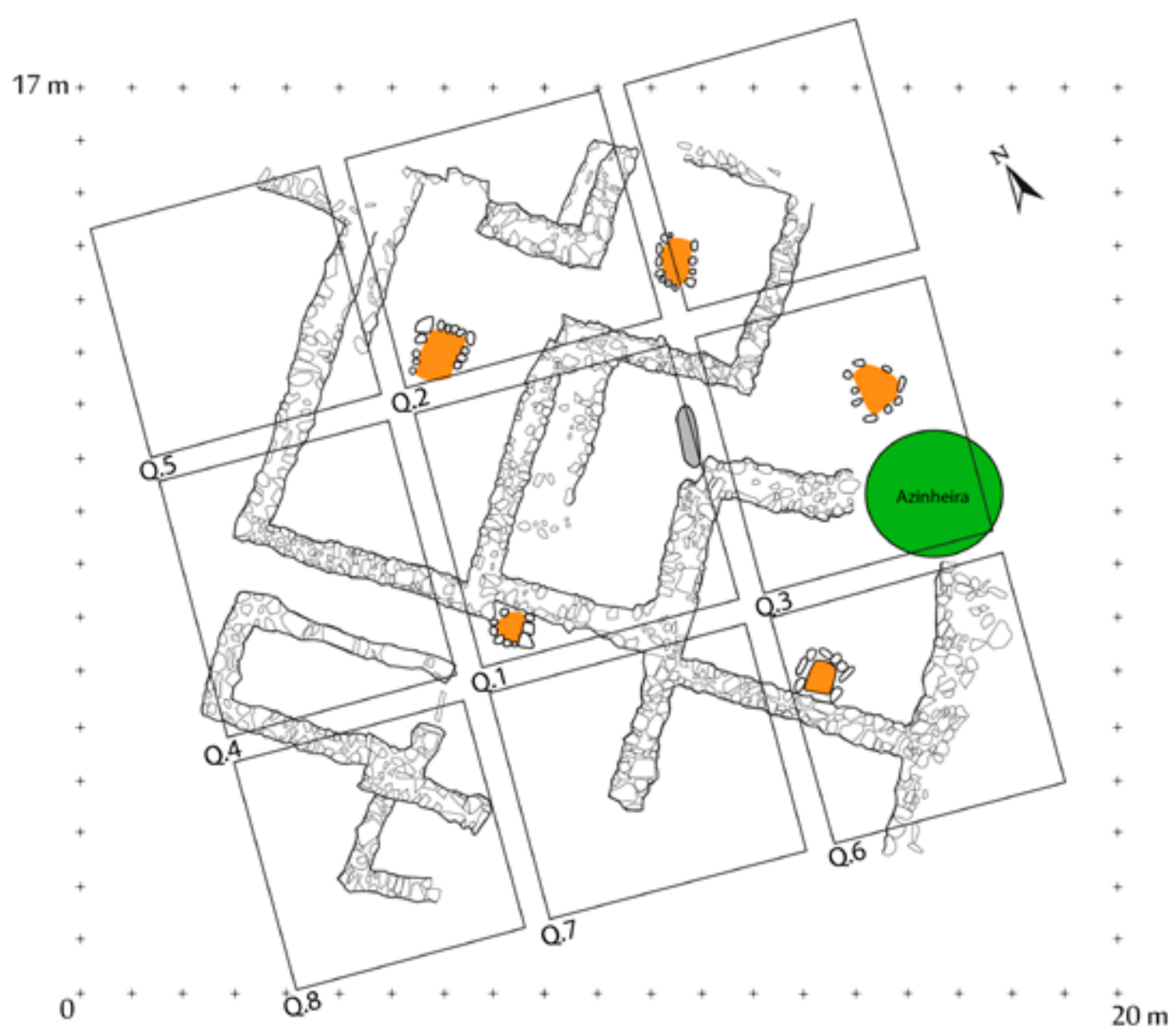

Figura 7 - Arquitectura de Castañuelo e quadriculagem da escavação de Mariano del Amo (Elaborado a partir de Amo, 1978, p. 302, fig. 1; Jiménez Ávila, 2009, fig. 3).

Por fim e no que diz respeito ao assunto aqui tratado, notamos a existência de vários recipientes grafitados em El Castañuelo, nomeadamente tigelas de cerâmica manual tosca totalmente grafitadas tanto por fora como por dentro, potes de pequena e média dimensão totalmente grafitados na superficie exterior (Fig. 9, $\mathrm{n}^{\mathrm{o}} 1-6$ ), bem como potes ou talhas de grandes dimensões, com uma larga faixa grafitada no exterior e sobre o bordo (Fig. 9, no 7-11). Em alguns destes recipientes de maior dimensão foi possível detectar a presença de um engobe esbranquiçado na metade inferior das peças. Além disso, notamos a peça número 10 (Fig. 9), a qual consiste numa talha de grande dimensão, grafitada numa larga faixa sob o bordo e que possui uma digitação ondulante que serve de limite ao grafitado.

Um dos potes de menor dimensão apresenta algumas particularidades dignas de nota (Fig. 9, n ${ }^{\mathbf{0}}$
6), nomeadamente o bordo actual, o qual resulta de um desbaste e polimento intencional da fractura, possivelmente efectuado após uma quebra acidental do bordo original. Além disso, possui uma perfuração na pança, próximo à zona do fundo. Esta característica torna-o muito semelhante ao pote do Cabeço Redondo já antes comentado (Fig. 4, no ${ }^{\circ}$ ), o qual possui igualmente uma perfuração junto ao fundo. Ignoramos a verdadeira funcionalidade desta perfuração, tanto mais que desconhecemos outra peça cerâmica com a mesma característica nos restantes sítios da Idade do Ferro deste território. Parece assim que a associação entre um pote grafitado e uma perfuração na base deverão ter um significado muito particular, pelo menos no que ao Cabeço Redondo e a El Castañuelo diz respeito, que não se parece poder aplicar a outros recipientes desprovidos desta decoração. (Fig. 9). 

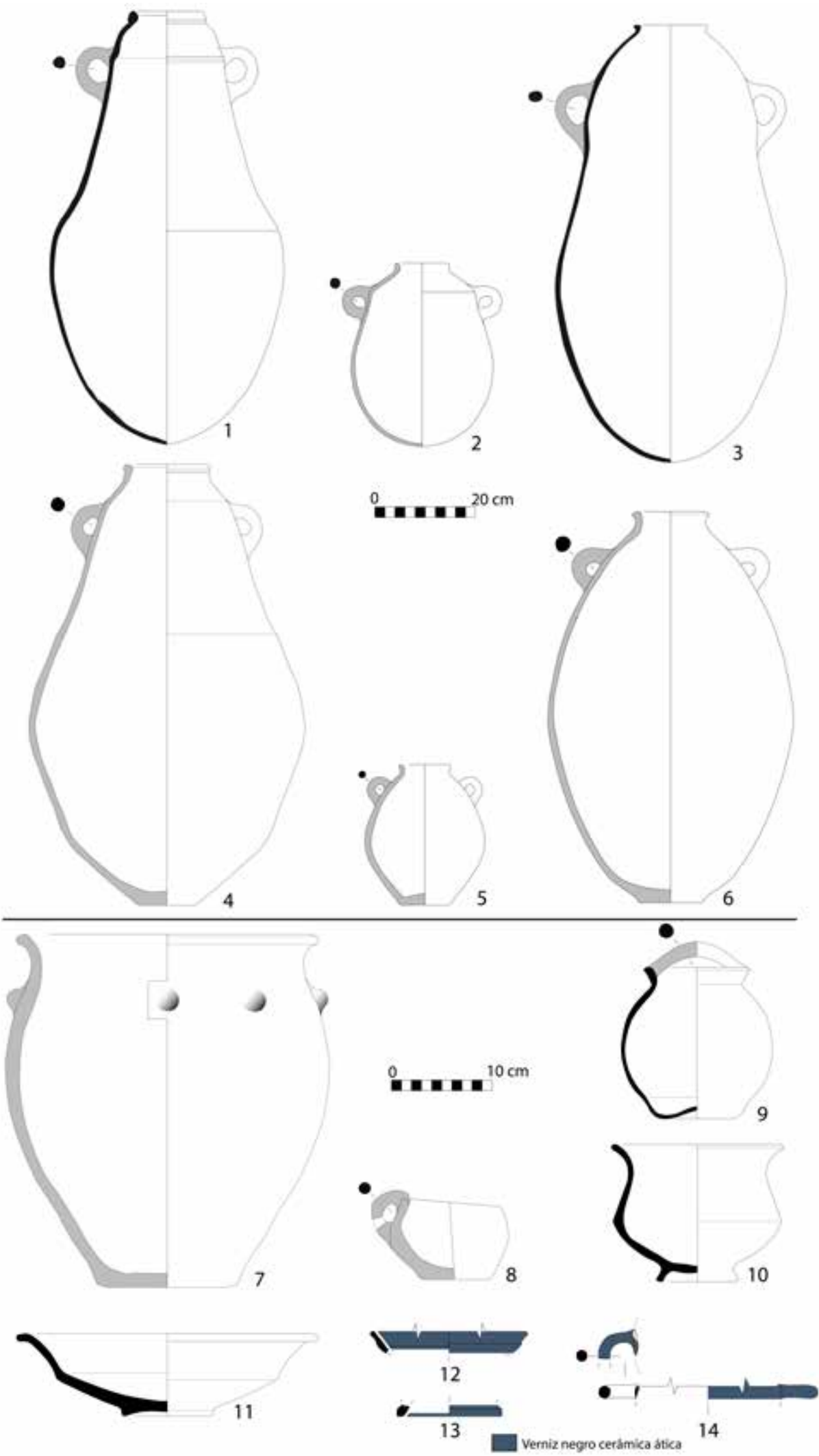

Figura 8 - Materiais de Castañuelo 


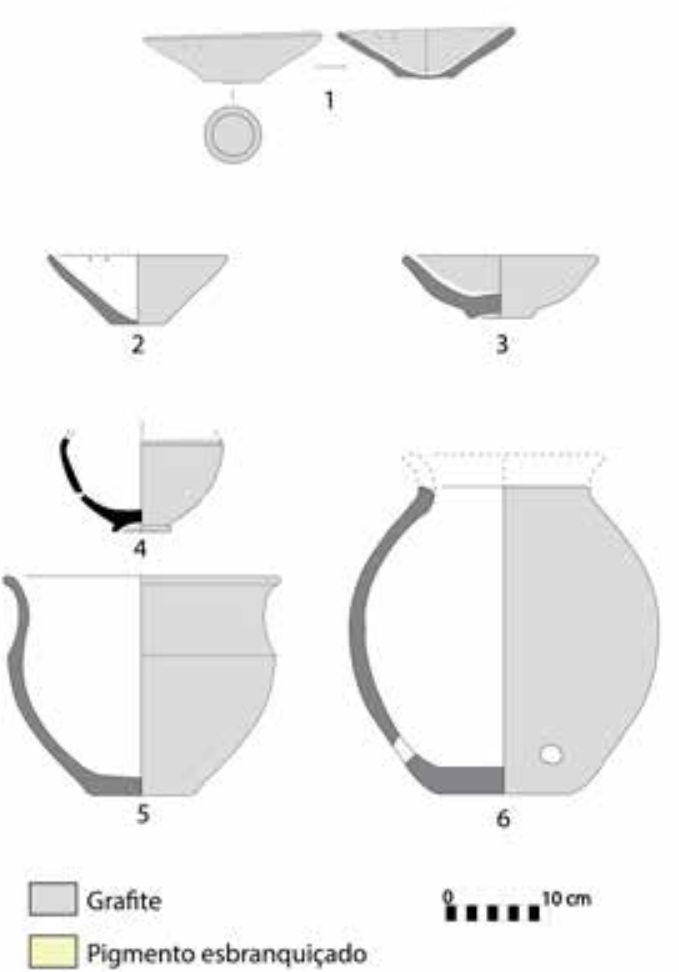

Figura 9 - Cerâmicas grafitadas de Castañuelo

O SÉculo IV A.C.

Castelo de Moura

O Castelo de Moura corresponde a um povoado de grande dimensão, o qual possui uma intensa ocupação da Idade do Ferro que se inicia e atinge o apogeu durante o século IV a.C.. Este povoado implanta-se sobre a colina do Castelo de Moura, um local de defensabilidade evidente, o qual beneficia inclusivamente de uma nascente de água abundante (Fig. 10). Este sítio arqueológico parece sair fora do tema desta análise, dado até agora não terem aí sido recuperadas cerâmicas grafitadas. No entanto, importa analisá-lo pelo facto do Castelo de Moura se situar a uns meros três quilómetros do Castro da Azougada e a cerca de vinte quilómetros do Castelo Velho de Safara, partilhando com estes sítios evidências de uma ocupação coincidente pelo menos durante os inícios do século IV a.C., como mais adiante veremos.

Este sítio foi pontualmente escavado por diversos investigadores (Soares, 2012, p. 8-11), tendo daí resultado um importante conjunto de materiais arqueológicos de várias cronologias, em especial no que aqui interessa, do século IV a.C.. Ainda que este
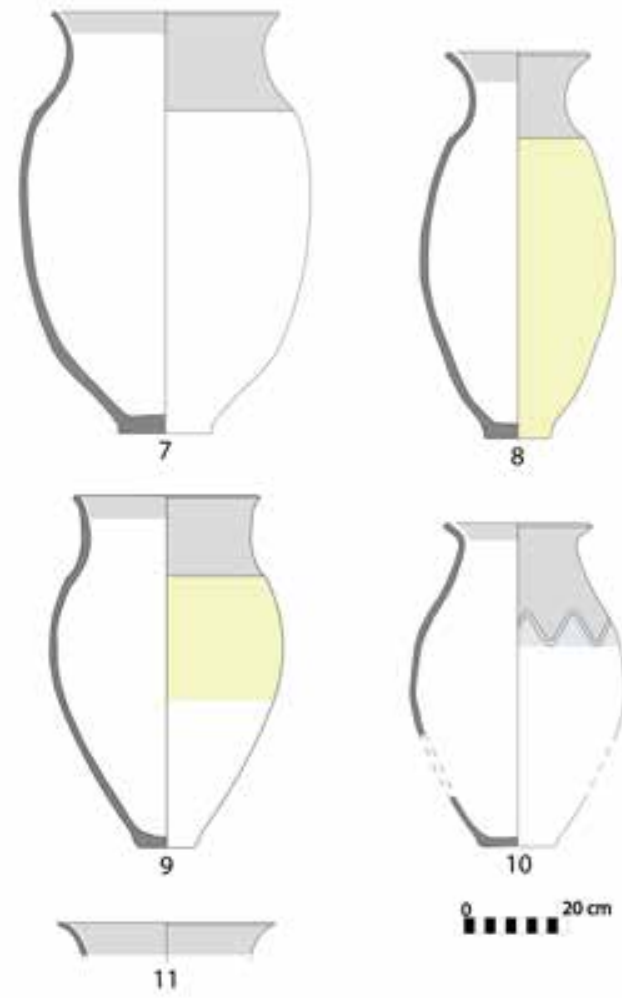

conjunto da Idade do Ferro se encontre absolutamente inédito, tive oportunidade de o observar no âmbito da tese de doutoramento que me encontro a realizar, estudando aprofundadamente o conjunto de materiais recuperados nas escavações efectuadas por José Gonçalo Valente em 2011 na zona do Posto de Recepção ao Turista (Fig. 10, zona assinalada a vermelho) (Valente e Soares, no prelo).

Entre estes materiais do século IV a.C., destacam-se as importações, com várias dezenas de fragmentos de cerâmica grega, onde abunda a cerâmica ática de figuras vermelhas, como os pratos do grupo do pintor de Viena 116 (Fig. 11, nº 7 e 8) e, mais raramente, um skyphos possivelmente atribuível ao grupo do Pintor Fat Boy (Fig. 11, n 1), bem como dois fragmentos aparentemente um de um lado A e outro do lado B de um krater atribuível ao Pintor do Tirso Negro, onde se destaca a cabeça de um sátiro em frente a um cacho de uvas, numa cena de banquete (Fig. 11, no 3 e 4). Encontram-se ainda vários fragmentos de cerâmicas áticas de verniz negro, como páteras das formas 21 e 22 (Fig. 11, n ${ }^{0} 5$ e 6) e um fragmento de um bordo da forma Jehasse 116 (Fig. 11, nº2). No que diz respeito às restantes 


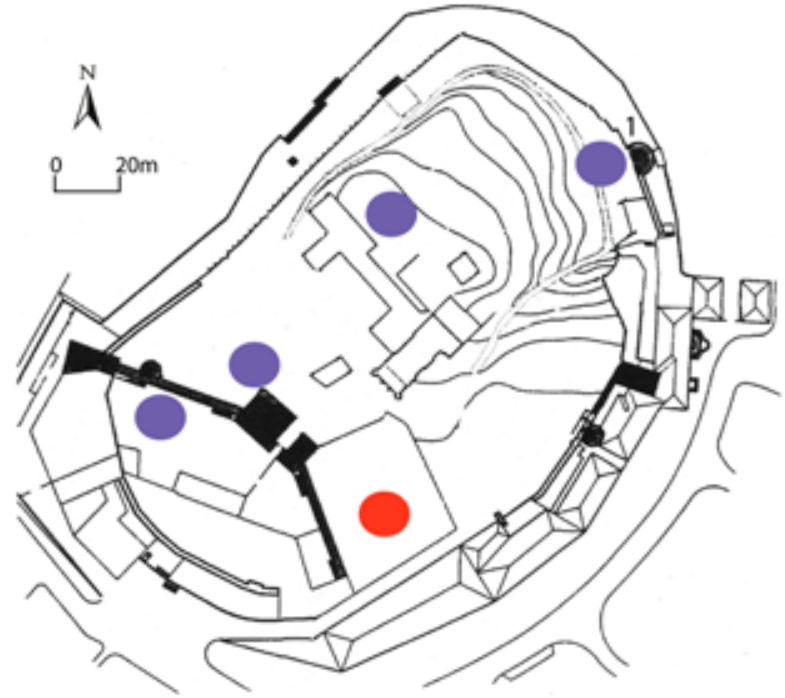

Figura 10 - Implantação do Castelo de Moura (modificado a partir de Macias ,1992, p. 133; Soares, 2012, fig. 9). Azul - diversos locais escavados. Vermelho escavação com materiais estudados

cerâmicas, destacam-se pela sua padronização e abundância alguns fragmentos de ânforas de produção local/regional (Fig. 12, n⿳0 10 e 11), com forma e pastas distintas das verificadas no século anterior em sítios como o Cabeço Redondo e em El Castañuelo; alguidares de perfil em "S" (Fig. 12, no 9) e numerosa cerâmica pintada, em especial algumas formas como potes e talhas, pintados de tons vermelho-vinhoso em faixas combinadas com traços ondulantes e/ou semi-círculos concêntricos repetitivos (Fig. 12, no 12-17), tigelas (Fig. 12, no 18-20) e pratos carenados (Fig. 12, n ${ }^{\mathrm{o}}$ 21-26).

\section{Castelo Velho de Safara}

Debruçando a atenção sobre o Castelo Velho de Safara, este correponde a um povoado muralhado implantado sobre um esporão rochoso, na confluência da ribeira de Safara com o rio Ardila (Fig. 13). Encontra-se datado da segunda metade do $1^{0}$ milénio a.C., desde meados do século IV até ao século I, através do conjunto de materiais recuperado em prospecção, estudado por Monge Soares (2001) e pela tese de mestrado de Teresa Costa (2010), onde figura a cerâmica grega de figuras vermelhas da primeira metade do século IV a.C., abundante cerâmica pintada, cerâmica tipo "Kuass", cerâmica estampilhada, recipientes fenestrados, cerâmica cinzenta, ânforas "ibero-púnicas", ânforas romanas republicanas e cerâmica de paredes finas, além de um abun- dante conjunto de cerâmica comum de tradição local-regional. Deste conjunto, para além da cerâmica ática, creio que alguns materiais de produção local/ regional podem ser, por comparação com o panorama verificado no Castelo de Moura, atribuídos com alguma segurança a uma cronologia do século IV, nomeadamente algumas formas de cerâmica pintada (Fig. 14, $\mathrm{n}^{\mathrm{O}}$ 2-6) e possivelmente alguns dos fragmentos de ânforas (Fig. 14, $\mathrm{n}^{\mathrm{o}}$ 1).

Sobre o tema aqui discutido, a cerâmica decorada com grafite, notamos a existência de um único fragmento de um pequeno recipiente aberto (Soares, 2001, p. 61, Fig. $7, \mathrm{n}^{\mathrm{o}}$ 51), possivelmente uma tigela, grafitado em banda sobre a superfície interior do bordo, possuindo uma banda vermelha no exterior (Fig. 14, nº 7).

\section{Castro da Azougada}

O Castro da Azougada (usualmente designado apenas por Azougada) implanta-se num pequeno cabeço de topo aplanado e vertentes muito inclinadas, excepto do lado Este, encontrando-se sobranceiro ao rio Ardila, próximo da sua junção com o rio Guadiana. Esta implantação num pequeno cabeço sobranceiro a um curso de água, faz de certa forma recordar a implantação do sítio de El Castañuelo, já anteriormente descrito.

A Azougada foi parcialmente escavada em várias campanhas por José Fragoso de Lima e Manuel Heleno, entre os anos de 1943 e 1951. Estas intervenções colocaram a descoberto uma ocupação com uma arquitectura de compartimentos pétreos construidos em torno de um páteo central (Fig. 15) e das quais resultou a recolha de um abundante conjunto de materiais sem contexto estratigráfico, onde se destaca a cerâmica grega dos séculos V e IV a.C., cerâmica de engobe vermelho de produção local, cerâmica pintada, numerosos metais e cossoiros, alguns vidros, osso trabalhado e líticos, encontrando-se este conjunto depositado no Museu Nacional de Arqueologia e no Museu Municipal de Moura.

Mais recentemente, durante o mês de Setembro de 2016 o Castro da Azougada seria novamente escavado pelo signatário deste artigo, no âmbito do seu projecto de doutoramento e do Plano de Investigação Pluri Anual aprovado pela Direcção Geral do Património Cultural, encontrando-se os dados recolhidos actualmente em tratamento e dos quais já foi possível divulgar algumas considerações (Nabais e Soares, no prelo). Desta intervenção resultou também um levantamento das estruturas pétreas 

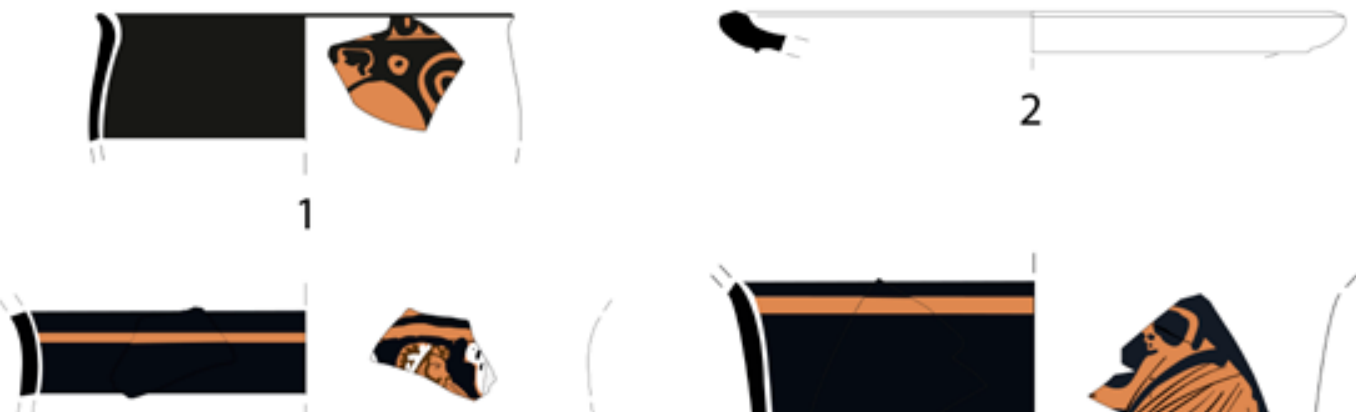

3
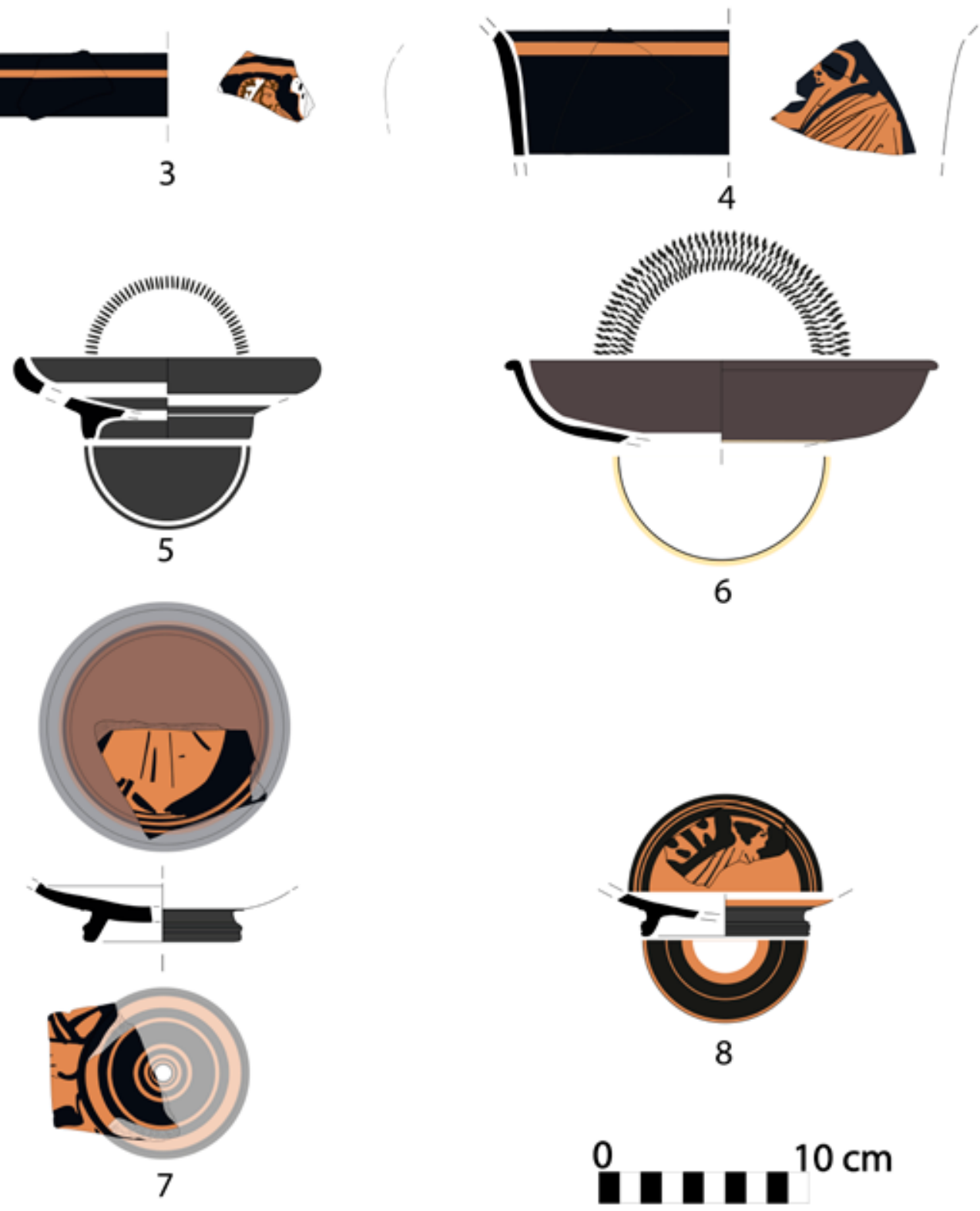

Figura 11 - Cerâmica ática do Castelo de Moura 
que se encontravam visíveis à superfície, o qual permitiu corrigir o "croquis" feito pelos escavadores dos anos 40, permitindo obter assim uma visão mais aproximada da disposição das estruturas então colocadas a descoberto (Fig. 15).

Sobre o conjunto de materiais recuperado nas escavações antigas, este foi parcialmente estudado por alguns autores, encontrando-se a visão mais actualizada sobre o sítio e os seus materiais em Soares (2012, p. 11-20, figs. 11-16).

No que diz respeito ao século $\mathrm{V}$, na Azougada encontra-se um numeroso conjunto de taças cástulo, algumas das quais completas (Fig. 16, no 419 e
420) e um fragmento de bordo e asa de um skyphos de bordo recto (Fig. 17, no 421). Para além das importações de cerâmica grega, e por comparação com os materiais do século V do Cabeço Redondo (Fig. 3) e de El Castañuelo (Fig. 8), situo também alguma da cerâmica de produção local/regional, como as ânforas e uma miniatura (Fig. 16, nº 389 e 384), cerâmicas fabricadas ao torno como os alguidares e os potes de asa de cesta (Fig. 16, $\mathrm{n}^{\mathrm{o}} 212$ e 244), a cerâmica manual, como os potes com decoração plástica e os púcaros (Fig. 16, nº359 e 362), a cerâmica cinzenta, nomeadamente os pratos e os vasos carenados (Fig. 16, no 45 e 223), ou ainda um prato
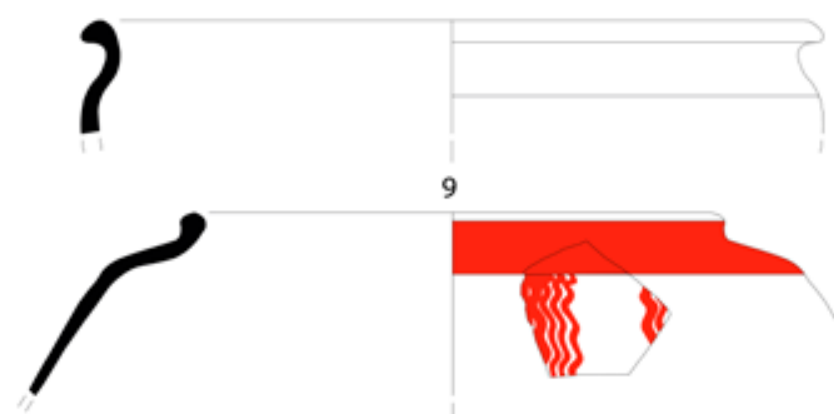

9

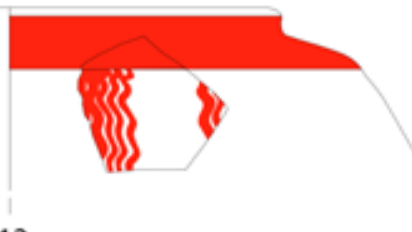

12
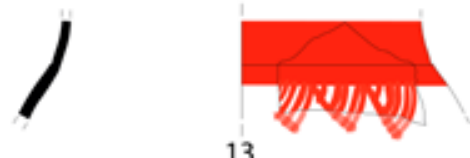

13

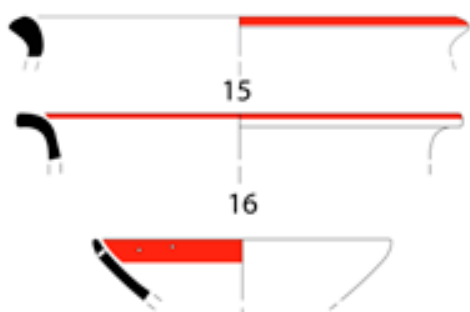

18

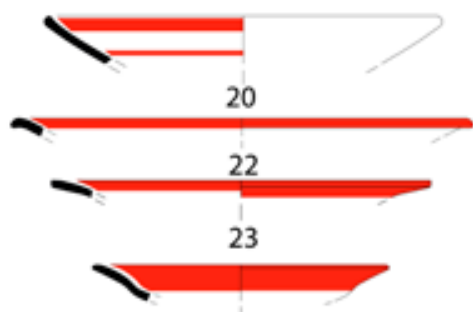

25

Pintura vermelho vinhoso
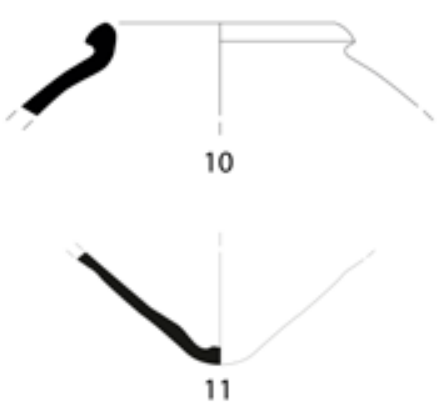

11
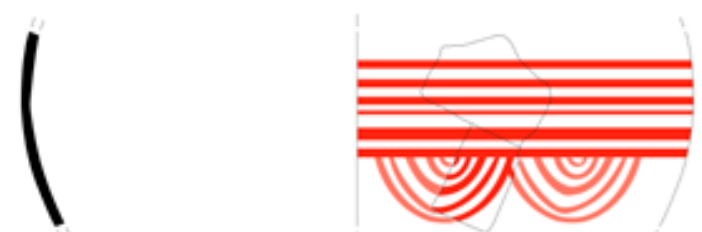

14

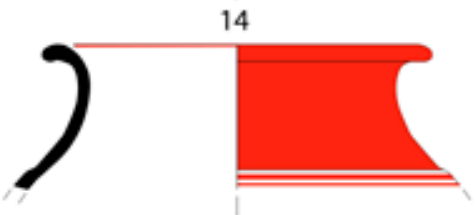

17

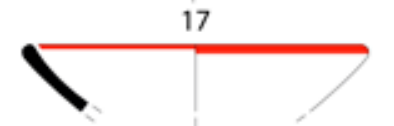

19

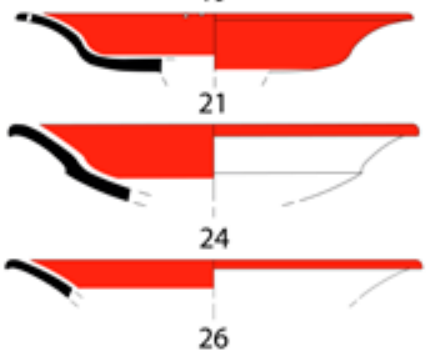

$0.10 \mathrm{~cm}$

Figura 12 - Cerâmica comum e pintada do Castelo de Moura 


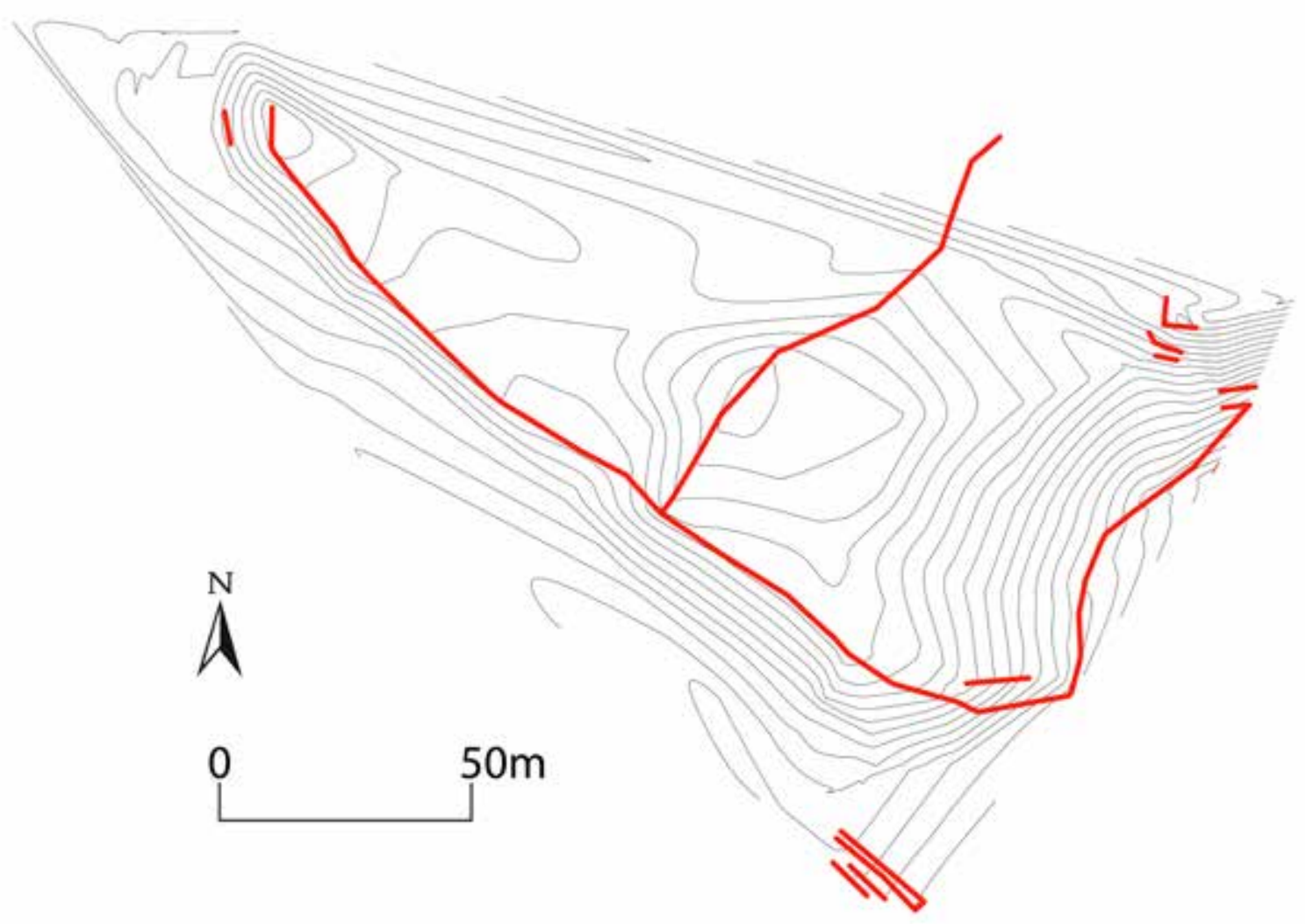

Figura 13 - Implantação Castelo Velho Safara (modificado a partir de Costa, 2010, mapa 6)

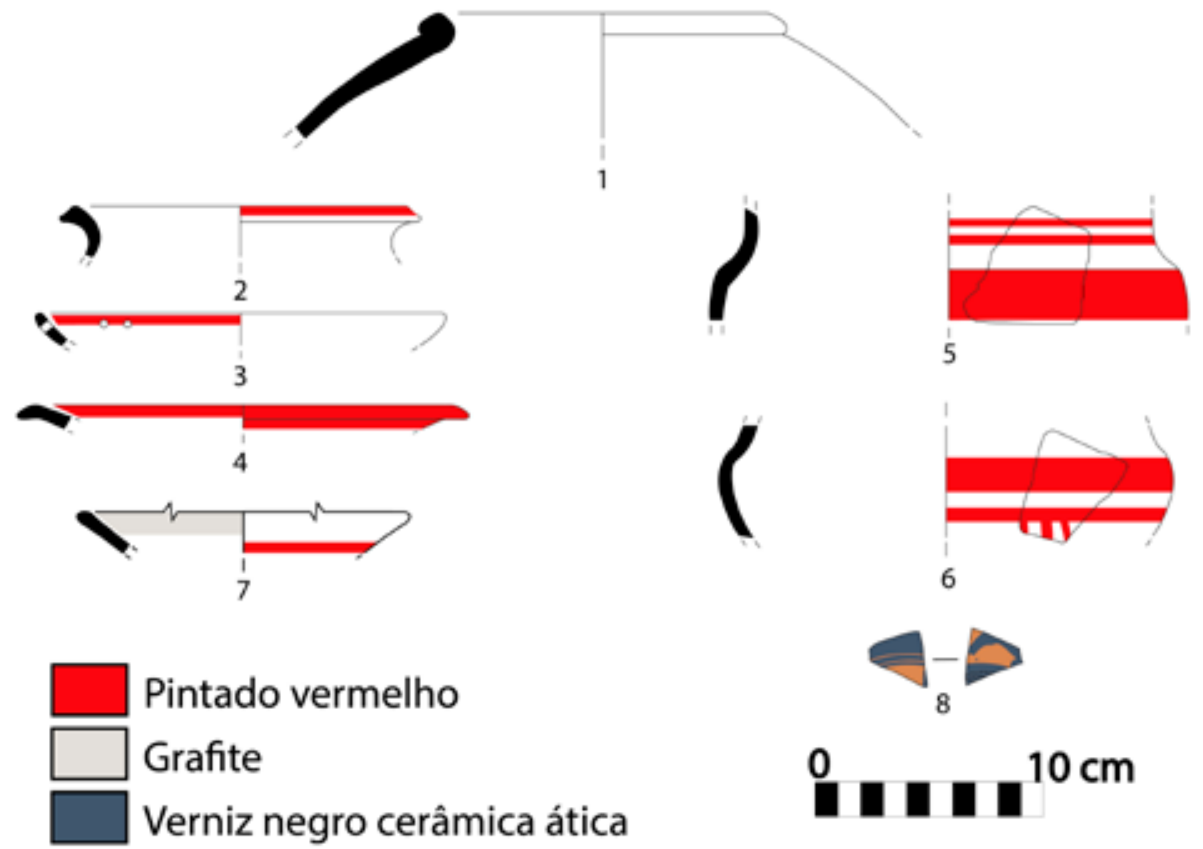

Figura 14 - Cerâmica grafitada e materiais do século IV do Castelo Velho Safara (elaborado a partir de Soares, 2001 e Costa, 2010) 
carenado pintado de vermelho, com faixa em reserva próximo do fundo exterior (Fig. 16, $\mathrm{n}^{\mathrm{o}}$ 11).

Já do século IV a.C., no Castro da Azougada foram recuperados vários fragmentos de taças do pintor de Vienna 116 (Fig. 17, $n^{\circ} 417$ ), alguns fragmentos de páteras da forma 22 de Lamboglia (Fig. 17, $\left.\mathrm{n}^{\mathrm{o}} 415\right)$, um fragmento de fundo de um bolsal com uma palmeta impressa (Fig. 17, no 418) e um fragmento de uma tampa de lekanis (Fig. 17, $\mathrm{n}^{\mathrm{0}}$ 416), a qual constitui uma peça algo rara nestes contextos, mas que se verifica na península Ibérica desde século $\mathrm{V}$ a.C., sendo mais abundante durante o século IV a.C. (Jiménez Ávila e Ortega Blanco, 2004, p. 142). No que diz respeito às cerâmicas de produção local/ regional desta cronologia, encontram-se raros fragmentos de ânforas (Fig. 17, $\mathrm{n}^{\mathrm{o}}$ 386) absolutamente idênticas na forma e na pasta às produções identificadas no Castelo de Moura (Fig. 12, nº 10 e 11), raros fragmentos de alguidares de perfil em "S" (Fig. $\left.17, \mathrm{n}^{\circ} 207\right)$ e numerosos, mas muito fragmentados, restos de cerâmica pintada de vermelho vinhoso, em bandas e em círculos concêntricos, com peças notavelmente idênticas na forma e no fabrico às do Castelo de Moura, como por exemplo, os pratos carenados pintados de vermelho vinhoso no interior (Fig. 17, $\mathrm{n}^{\circ} 3$ e 414).

Sobre as cerâmicas grafitadas do Castro da Azougada, a maioria (vinte e três peças) já se encontra publicada (Antunes, 2005; 2009), encontrado-se ainda algumas inéditas (seis peças), quer no Museu Municipal de Moura, quer no Museu Nacional de Arqueologia, sendo aqui a presentadas pela primeira vez (Fig. 18, no 422 e 427; Fig. 19, no 423-426).

No que diz respeito às peças que já se encontram publicadas, algumas a presentam determinados problemas de registo, pelo que me parece ser esta uma oportunidade para apresentar a sua rectificação. Assim, as peças no 31 e 32 (Antunes, 2009, p. 124) não possuem qualquer grafite sobre o bordo, antes uma faixa bastante queimada, que me parece um bom indicador de que as peças terão sido utilizadas como tampas de recipientes expostos ao lume, pelo que não deverão ser consideradas peças grafitadas. Já a peça $\mathrm{n}^{\mathrm{o}} 30$ (Idem), possui uma representação errada da decoração das bandas de grafite e do engobe vermelho, tanto no interior como no exterior da peça, pelo que aqui apresentamos o desenho corrigido (Fig. 18, $\mathrm{n}^{\mathrm{o}}$ 30). Semelhante questão ocorre com a peça $\mathrm{n}^{\circ} 25$ (Antunes, 2009, p. 123), a qual surge com uma faixa grafitada próximo do interior do fundo. No entanto, esta faixa não existe,

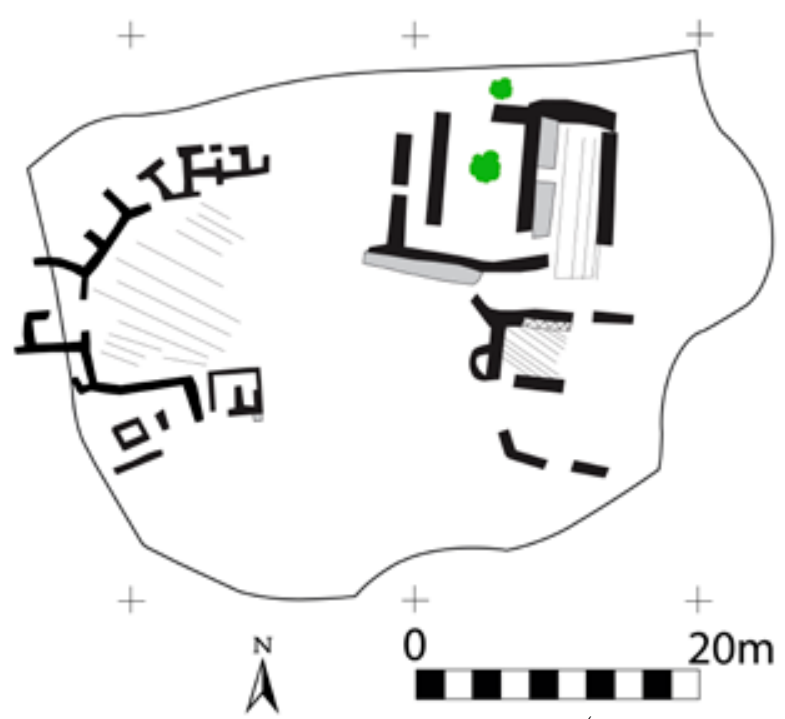

Figura 15 - Arquitectura da Azougada ("Croquis" dos anos 40, corrigido e modificado a partir de (Soares, 2012, Fig. 13), com base num levantamento topográfico efectuado em 2016 pelos serviços da Câmara Municpal de Moura).

estando a grafite no interior da peça limitada à faixa sobre o bordo, encontrando-se o restante da superfície interior coberta de engobe vermelho. Também a peça $\mathrm{n}^{\circ} 34$ (Antunes, 2009, p. 126), apesar de representada como uma tigela, na realidade o seu bordo não existe, pois esta peça encontra colagem com os fragmentos $\mathrm{n}^{\circ} 35$ e 36 (Idem), correspondendo assim a um pote carenado (Fig. 19, n ${ }^{\circ} 34$ ). Ainda no campo das colagens, notamos que as peças № 19 e 21 (Antunes, 2009, p. 122) colam, correspondendo à mesma peça. Já os fragmentos $\mathrm{n}^{\circ} 1 \mathrm{e}$ 2 (Idem, p. 117), ainda que não colem, penso que é importante notar que dada a semelhança que apresentam, poderão com grande probabilidade corresponder à mesma peça, tal como sucede com as peças 26 e 27 (Ibidem, p. 123), que se encontram nas mesmas condições. Verifico também que as peças 17 e 18 (Antunes, 2009, p. 121) se encontram com os números de inventário do MNA trocados $\left(\mathrm{N}^{\mathrm{o}} 17=\right.$ MNA2003.41.1; № 18= MNA2003.21.2). Por fim, é importante notar uma peça que se encontrava classificada como cerâmica de engobe cinzento (Antunes, 2009, p. 208, no 98), mas que corresponde à única tigela completamente coberta de grafite do Castro da Azougada (Fig. 18, n⿳0 98), a qual já anteriormente havia comentado (Soares, 2012, p. 25).

Passando à análise desta decoração, do Castro da Azougada conhecemos o conjunto mais diversifica- 


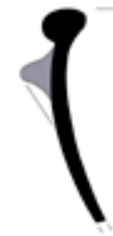

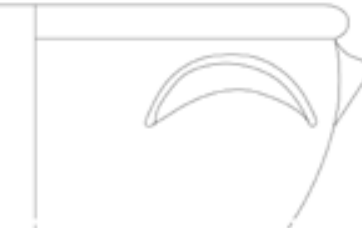

212

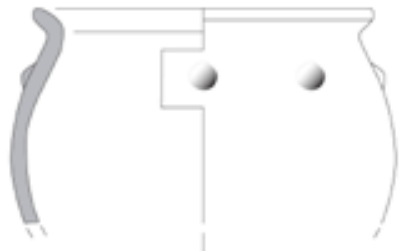

359

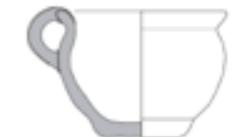

362
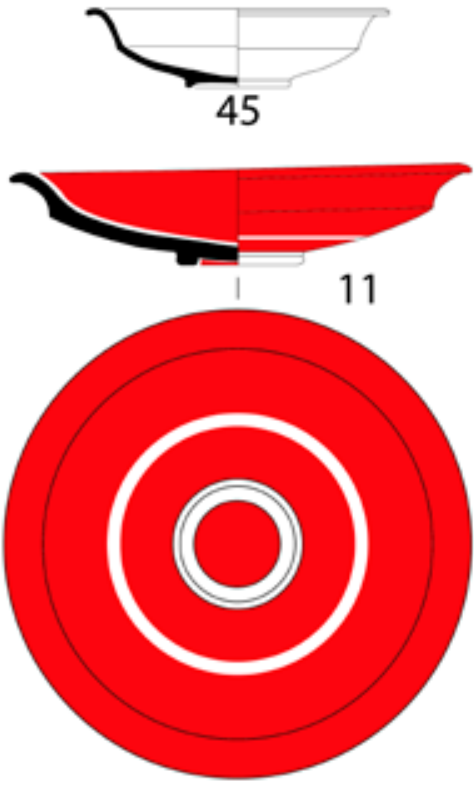

Pintado vermelho Verniz negro cerâmica ática

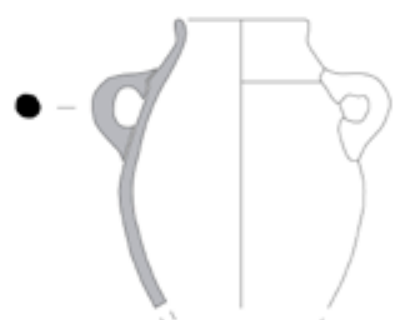

384

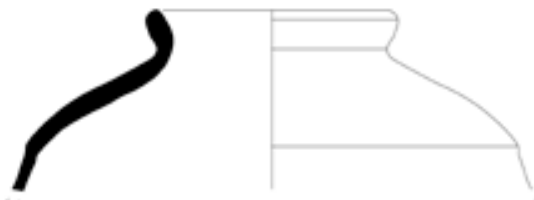

389
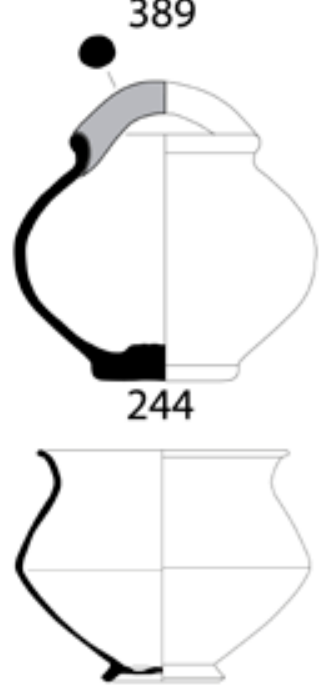

223
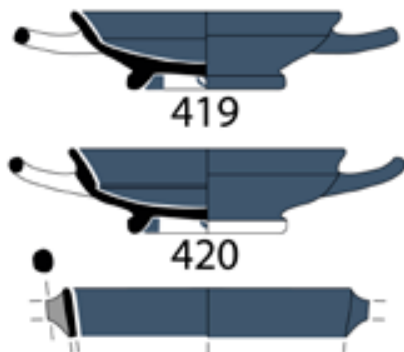

421

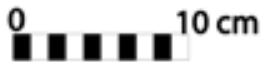

Figura 16 - Materiais do s. V a.C. da Azougada (parcialmente elaborado e modificado com base em Antunes, 2005). 


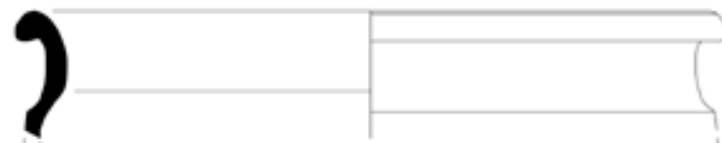

207

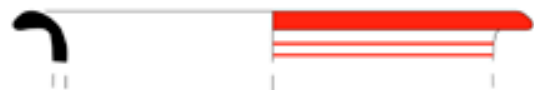

266

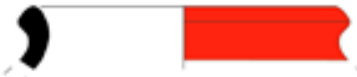

302
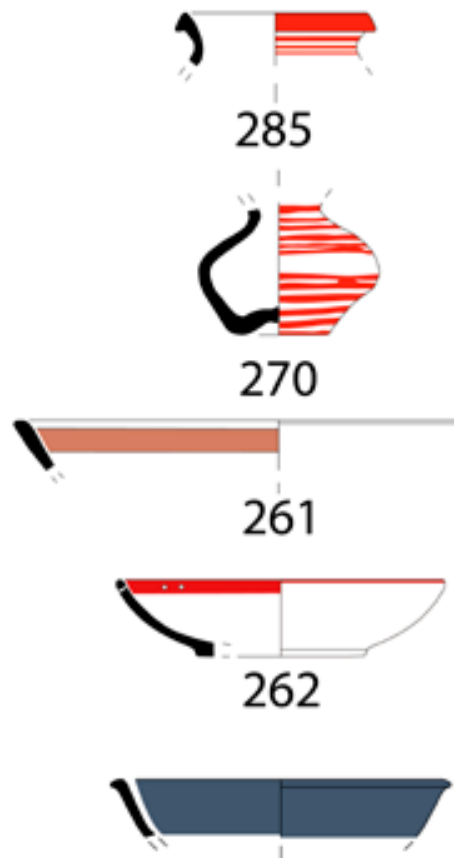

415

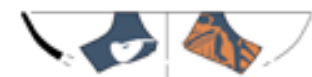

417

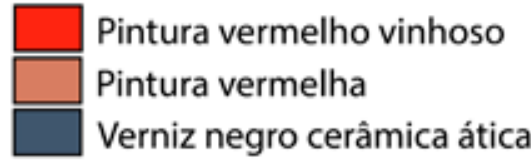

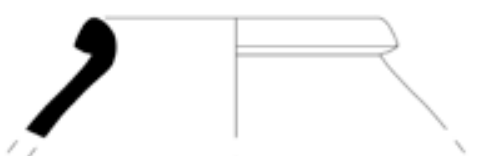

386
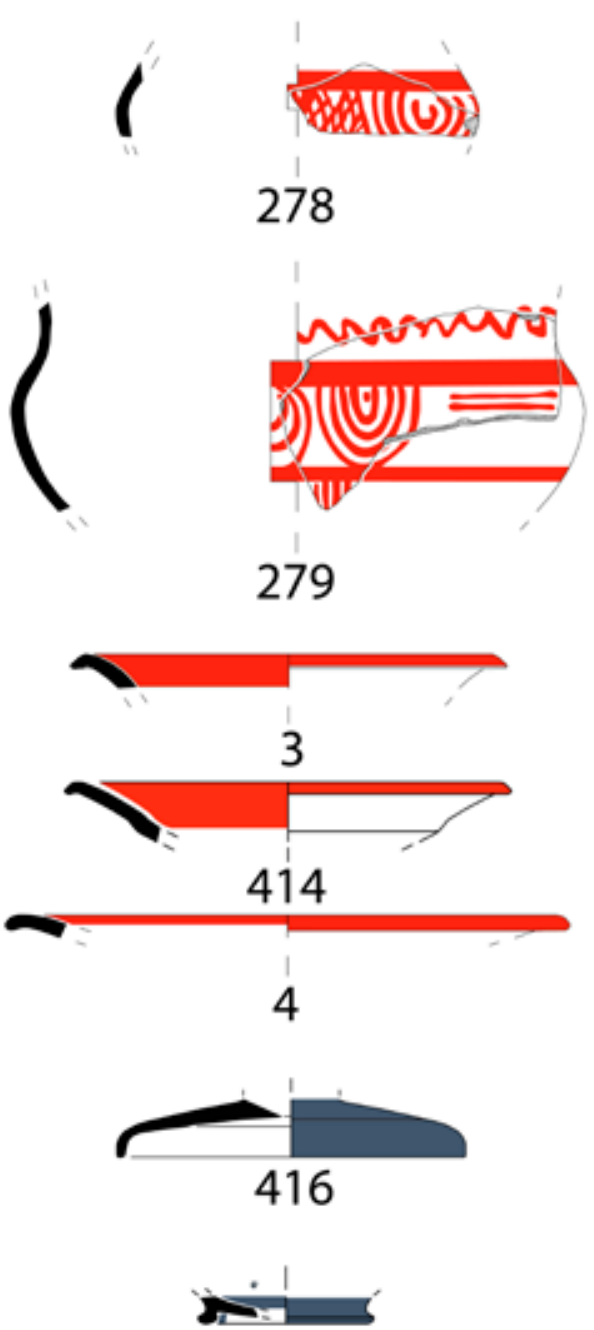

418

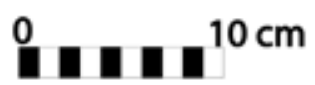

Figura 17 - Materiais do s. IV a.C. da Azougada (parcialmente elaborado e modificado com base em Antunes, 2005). 
do e numeroso de cerâmica grafitada no território em estudo, com recipientes principalmente grafitados em bandas, sempre alternadas com bandas de engobe vermelho, principalmente em tigelas, pratos e potes de pequena dimensão, aparentemente encontrando-se ausentes recipientes de grande dimensão como talhas (Fig. 18 e 19).

Em relação a outros aspectos decorativos, verifica-se a existência de algumas peças na Azougada onde se regista a presença de caneluras no exterior das peças, podendo estas caneluras servir uma função decorativa ou, possivelmente, uma função mais prática, de permitir melhor aderência às mãos do utilizador (Fig. 18, no 25, 26/27 e 422; Fig. 19, no 38). Nota-se também a presença de vários recipientes onde se regista a existência de duas perfurações sobre o bordo das peças (Fig. 18, no 17, 18, 19/21, 20 e 25; Fig. 19, no 1/2), cuja função tem sido alvo de debate (Soares, 2012, p. 51-53), parecendo como hipótese mais provável que estas poderiam servir para a suspensão da peça por meio de um cordel que passaria nas perfurações.

As FORMAS E A VARIEDADE DECORATIVA: APRECIAÇÕES GLOBAIS

Observando de forma global as morfologias cerâmicas e as variedades decorativas da cerâmica grafitada no território aqui estudado, evidencia-se que as formas cerâmicas onde ocorre esta decoração constituem-se principalmente por pequenos recipientes abertos como tigelas e pratos, pequenos recipientes fechados como potes/panelas e ainda por recipientes fechados de média/grande dimensão, estando presentes tanto em peças fabricadas ao torno como em cerâmica manual. Notamos também a sua total ausência em algumas formas comuns nesta

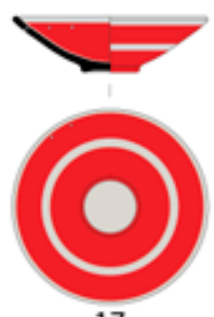

17

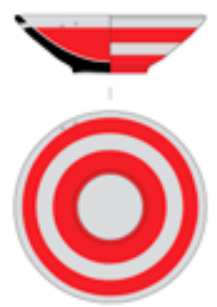

18

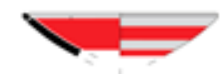

$19 / 21$

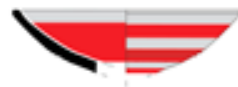

$26 / 27$

Grafite

Engobe vermelho

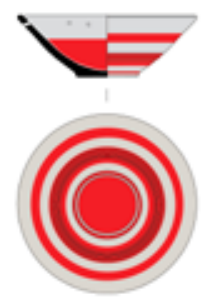

25

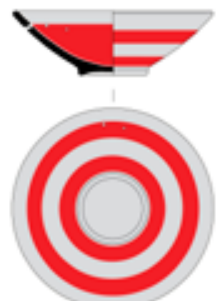

20

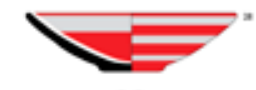

28

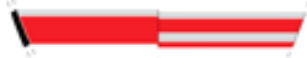

22

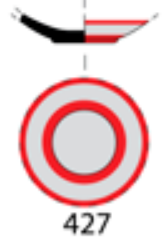

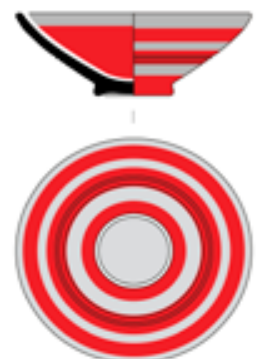

422

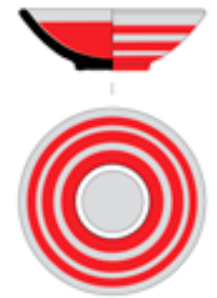

29

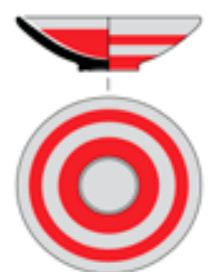

30

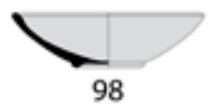

1. I. $10 \mathrm{~cm}$

Figura 18 - Tigelas grafitadas da Azougada. (parcialmente elaborado e modificado com base em Antunes, 2005) 
cronologia, como por exemplo em bacias /alguidares, potes de asa de cesto, ânforas, entre outras, facto que permite supor que a função de cada recipiente justifica a presença ou ausência de decoração.

Em relação aos motivos decorativos no conjunto de sítios enunciados, regista-se a presença de alguns exemplares no Cabeço Redondo (Fig. 4, no 6 e 7), em Castañuelo (Fig. 9, n⿳0 1-3) e de um exemplar na Azougada (Fig. 18, $\mathrm{n}^{0}$ 98), de tigelas integralmente cobertas com grafite. Sobre estas peças, notamos que os exemplares de Castañuelo são todos de cerâmica manual grosseira, enquanto que os fundos do Cabeço Redondo e o exemplar único da Azougada são de cerâmica feita ao torno.

Já as tigelas grafitadas em bandas, alternadas com bandas de engobe vermelho, encontram-se exclusivamente em exemplares provenientes do Castro da Azougada (Fig. 18). A única peça que se aproxima ou assemelha deste modelo de faixas de grafite alternadas com engobe vermelho, estabele- cido no Castro da Azougada, encontra-se no único exemplar conhecido no Castelo Velho de Safara, numa peça que aparentemente corresponderá a uma tigela com uma banda grafitada sobre o bordo, combinada com uma faixa vermelha pintada (Fig. $\left.14, \mathrm{n}^{\mathrm{o}} 7\right)$. Concluindo o que às tigelas diz respeito, parece importante referir que nenhum dos exemplares decorados com engobe vermelho possui grafite no interior do fundo, facto talvez relacionado com a funcionalidade destas peças, e que algumas tigelas possuem o exterior do fundo grafitado (Fig. $18, \mathrm{n}^{\mathrm{0}} 17,18,20,29,30,422$ e 427). Este facto, da presença da decoração de grafite aplicada na base das peças, não deixa de ser notável, em especial no que diz respeito às peças grafitadas em bandas, onde o impacto decorativo acaba por ser bastante evidente, caso as peças se encontrassem voltadas com o bordo para baixo. A este propósito, assinalamos precisamente o facto de alguns destes recipientes possuirem a dupla-perfuração sobre o bordo, a qual

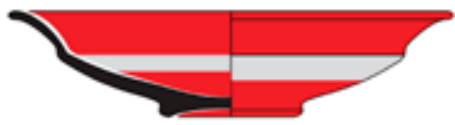

423

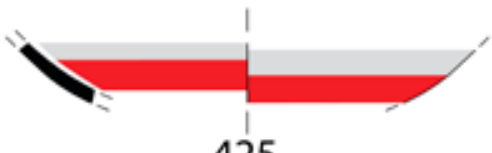

425

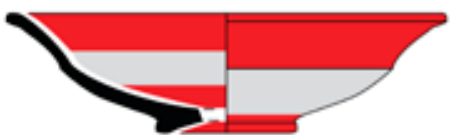

424

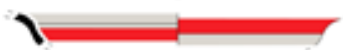

12

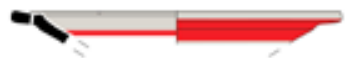

$1 / 2$

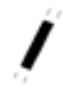

23

24

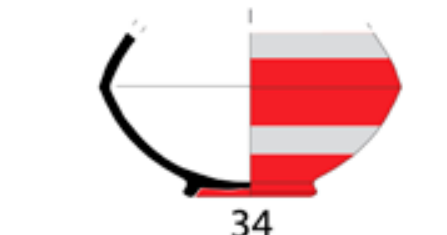

34

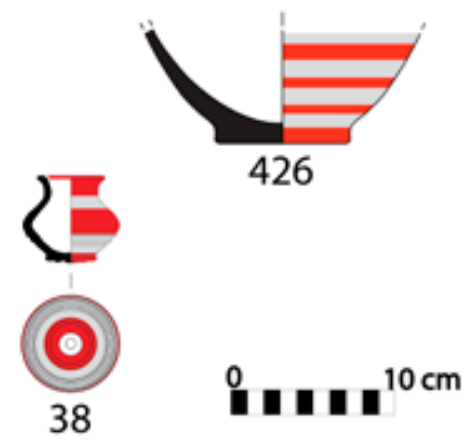

Figura 19 - Cerâmica Grafitada da Azougada (parcialmente elaborado e modificado com base em Antunes, 2005) 
tem sido por vezes associada à utilização das tigelas como tampas, servindo a pefuração para a colocação de um cordel, o qual seria igualmente atado ao colo de um pote. Em todo o caso, se parece provável que estas peças tenham sido utilizadas como tampas, não eram seguramente tampas de panelas que iam ao lume, pois em nenhum dos exemplares se registam as marcas de fogo habituais nestes casos.

Muito mais raros que as tigelas, encontram-se os pratos, até agora todos exclusivamente encontrados na Azougada, revelando a presença de bandas grafitadas alternadas com engobe vermelho (Fig. 19, $\mathrm{n}^{\mathrm{o}} 423-425,1 / 2$ e 12). Um deles apresenta o mesmo tipo de perfuração no bordo que as tigelas (Fig. 19, $\mathrm{n}^{\mathrm{o}} 1 / 2$ ) e nenhum dos dois exemplares com fundo preservado apresenta grafite na parte inferior do pé.

No que diz respeito aos recipientes fechados de pequena e média dimensão, nomeadamente potes, em geral esta morfologia é rara, podendo as decorações ser tanto o grafitado total da peça no exterior, encontrando-se presente no Cabeço Redondo (Fig. 4, no 4, 5 e 8) e em El Castañuelo (Fig. 9, no 4-6), como o grafitado em bandas alternadas com engobe vermelho, no Castro da Azougada (Fig. 19, $\mathrm{n}^{\mathrm{o}}$ 23, 24, 34, 38 e 426).

Por fim, registam-se potes ou talhas de grande dimensão. Correspondem a peças provenientes exclusivamente do Cabeço Redondo (Fig. 4, no 1-3) e de El Castañuelo (Fig. 9, no 7-11), e apresentam uma larga faixa grafitada aplicada sobre a zona do bordo. Foi possível verificar que algumas das talhas de Castañuelo possuem um engobe ou pintura esbranquiçada entre a faixa de grafite e o fundo ou o meio da peça (Fig. 9, no 8 e 9) e que um dos exemplares apresenta uma digitação ondulante que serve de limite à faixa de grafite (Fig. 9, no 10).

\section{DISCUSSÃO}

Feita esta apresentação do panorama geral das cerâmicas grafitadas encontradas entre a margem esquerda do Guadiana e a Serra de Aracena e dos seus contextos, creio ser pertinente tentar estabelecer uma cronologia para esta decoração. Se as cerâmicas grafitadas do Cabeço Redondo e de El Castañuelo não parecem colocar obstáculos a uma cronologia do século $\mathrm{V}$ a.C., dado que os sítios se parecem fechar nesse século, o mesmo não se pode dizer em relação ao Castro da Azougada e ao Castelo Velho de Safara, sítios com uma cronologia mais dilatada e com conjuntos de materiais recuperados sem registo estratigráfico. Assim, ponderamos al- guns apontamentos sobre as semelhanças e diferenças entre os cinco sítios mencionados nesta análise, por forma a tentar estabelecer uma cronologia fiável para a decoração destes dois sítios problemáticos. Por um lado, temos os recipientes totalmente grafitados ou grafitados numa larga faixa sobre o bordo, do Cabeço Redondo e de El Castañuelo, além da tigela totalmente grafitada da Azougada. Por outro, temos a semelhança entre as tigelas de bandas de grafite alternado com engobe vermelho do Castro da Azougada e a peça do Castelo Velho de Safara, grafitada sobre o bordo, possuindo uma faixa pintada de vermelho no exterior.

Para além das semelhanças e diferenças ao nível da decoração grafitada, evidenciam-se também algumas diferenças ao nível dos conjuntos cerâmicos dos sítios mencionados, com a presença de cerâmica àtica do século V a.C. no Cabeço Redondo (Fig. 3, $\mathrm{n}^{\mathrm{o}} 9$ e 10), em El Castañuelo (Fig. 8, no 12-14) e na Azougada (Fig. 16, no 419-421), encontrando-se até agora ausente no Castelo Velho de Safara e no Castelo de Moura. Também formas como os pratos carenados e pintados de vermelho do Cabeço Redondo (Fig. 3, nº 8) encontram paralelo numa peça inteira da Azougada (Fig. 16, n⿳0 11), tal como sucede com alguns alguidares destes dois sítios (Fig.3, $\mathrm{n}^{\mathrm{o}} 2$ e 3; Fig. 16, n⿳⺈ 212) absolutamente idênticos na forma e no fabrico. Outras peças, como os púcaros, os pratos e os potes carenados de Castañuelo (Fig. 8, n⿳o 8, 10 e 11), encontram peças idênticas na Azougada (Fig. 16, no 362, 45 e 223), partilhando estes dois sítios ainda mais alguns pormenores interessantes como a fabricação em cerâmica manual de imitações de ânforas em miniatura (Fig. 8, no 2 e 5; Fig. 16, n⿳0 384).

Por outro lado, a cerâmica ática do século IV a.C. apenas se encontrou no Castelo de Moura (Fig. 11), no Castelo Velho de Safara (Fig. 14, no 8) (Soares 2001; Costa 2010) e na Azougada (Fig. 17, no 415-418). Tambem notável, constitui a diferença nas quantidades e nos motivos decorativos da cerâmica pintada, a qual existe em grande quantidade no Castelo de Moura (Fig. 12), no Castelo Velho de Safara (Fig. 14) e na Azougada (Fig. 17), encontrando-se bastante rara no Cabeço Redondo e em Castañuelo, sendo que nestes dois últimos os motivos decorativos como os círculos concêntricos e as linhas ondulantes se encontram até agora absolutamente ausentes.

Uma das evidências que decorrem desta observação e que me parecem um pormenor digno de 
nota, é o facto de vários materiais do século V a.C. na Azougada corresponderem a peças inteiras ou quase inteiras, enquanto os materiais do século IV a.C. com cronologia segura, se encontram todos extremamente fragmentados e incompletos. Além disso, a quantidade de materiais atribuíveis ao século IV a.C. parece ser proporcionalmente muito inferior à quantidade de materiais do século $\mathrm{V}$ a.C.

Se estas observações forem verdadeiras, e se não resultarem de uma coincidência ou erro de análise, então penso que deverá existir uma razão que permita compreender este fenómeno. Uma possível explicação para este facto seria que, à semelhança do que se verifica em vários outros sítios com ocupações dos finais do século V a.C., a Azougada teria sido abandonada e os seus compartimentos amortizados com a cultura material abandonada in situ, ficando assim protegida debaixo dos derrubes das paredes, tendo desta forma sido recuperadas peças inteiras desta cronologia durante a escavação.

Posteriormente, e aqui residiria a excepcionalidade do Castro da Azougada em relação a outros sítios, o local seria novamente ocupado e construído durante o seculo IV a.C. sobre a amortização da ocupação anterior, sem que o fim dessa ocupação se processasse como a do século $\mathrm{V}$ a.C.. Sobre a menor quantidade de peças do século IV a.C., esta poderia talvez explicar-se por uma ocupação mais breve no tempo, ou por um espaço habitacional de muito menor dimensão que o que se verificara durante o século V a.C.. A ser assim, estas hipóteses explicariam a elevada fragmentação e as peças incompletas desta cronologia, bem como a possível ausência ou escassez de estruturas construtivas desta fase final. Por fim, penso que esta excepcionalidade da Azougada no panorama dos povoados do século $\mathrm{V}$ a.C., com uma reocupação no século IV a.C., se pode explicar com a proximidade deste sítio ao grande povoado do Castelo de Moura, do qual apenas dista cerca de três quilómetros.

Ressalvo que esta é apenas uma mera teoria, ainda bastante frágil, construída apenas com base na observação das cerâmicas e que carece de confirmação, em especial a nível estratigráfico, com novas escavações. Todavia, com base nesta hipótese e na organização cronológica que propus para as cerâmicas, noto que a esmagadora maioria da cerâmica grafitada deste sítio corresponde a peças recuperadas inteiras, pelo que a existir algo de verdadeiro na teoria aqui apresentada, então a maioria desta cerâmica deveria ser enquadrada no século $\mathrm{V}$
a.C.. Se for verdade, isto contraria totalmente o que em 2012 propus (Soares, 2012, p. 95), quando sugeri que estas se deveriam enquadrar no século IV a.C., em virtude de me parecerem próximas da peça grafitada encontrada no Castelo Velho de Safara e de serem diferentes das peças grafitadas recuperadas no Cabeço Redondo e em El Castañuelo. No entanto, face à recente análise dos materiais do século IV a.C. do Castelo de Moura, sítio que dista meros três quilómetros da Azougada e onde não se encontrou até agora qualquer vestígio de cerâmica grafitada, ou de engobe vermelho idêntico ao que decora as peças grafitadas da Azougada, penso agora que a explicação poderá ser outra. Assim, sendo a cerâmica grafitada da Azougada do século V a.C. e não se podendo explicar as diferenças decorativas pela via cronológica, então a explicação poderá residir em diferenças funcionais entre os sítios, ou em meras diferenças nos gostos/tradições decorativas de cada sítio, sem qualquer significado mais profundo. Em todo o caso, creio que este problema não se pode dar por resolvido e estas questões deverão ser mantidas em aberto por agora, até que escavações arqueológicas modernas na Azougada permitam obter confirmação estratigráfica para a cronologia da sua cerâmica grafitada.

\section{CONCLUSÕES}

O carácter de excepção da decoração grafitada, evidente pelo facto de ser a única decoração não-plástica aplicada aos recipientes de fabrico local do Cabeço Redondo e de El Castañuelo, traduz a sua relevância a nível regional durante o século $\mathrm{V}$, o que permite supor que, após o momento cronológico de ocupação do Cabeço Redondo e de El Castañuelo, e já durante a ocupação do Castelo de Moura, alguma transformação terá afectado os gostos decorativos das populações desta região. O Castro da Azougada permanece por enquanto único com a sua cerâmica grafitada em bandas com engobe, secundado pelo Castelo Velho de Safara, com uma peça que se parece aproximar decorativamente das primeiras.

Parece então plausível que a técnica da cerâmica grafitada terá chegado a esta região durante o século V a.C., vinda provavelmente da zona do Alto Guadalquivir, rio a cuja bacia hidrográfica pertence o sítio de El Castañuelo (Fig. 20). Por fim, a sua utilização parece ter-se extinguido ou nos finais do século V, ou durante o século IV a.C., tendo a parentemente ficado a sua dispersão confinada à margem esquerda do Guadiana e à bacia do rio Ardila. 


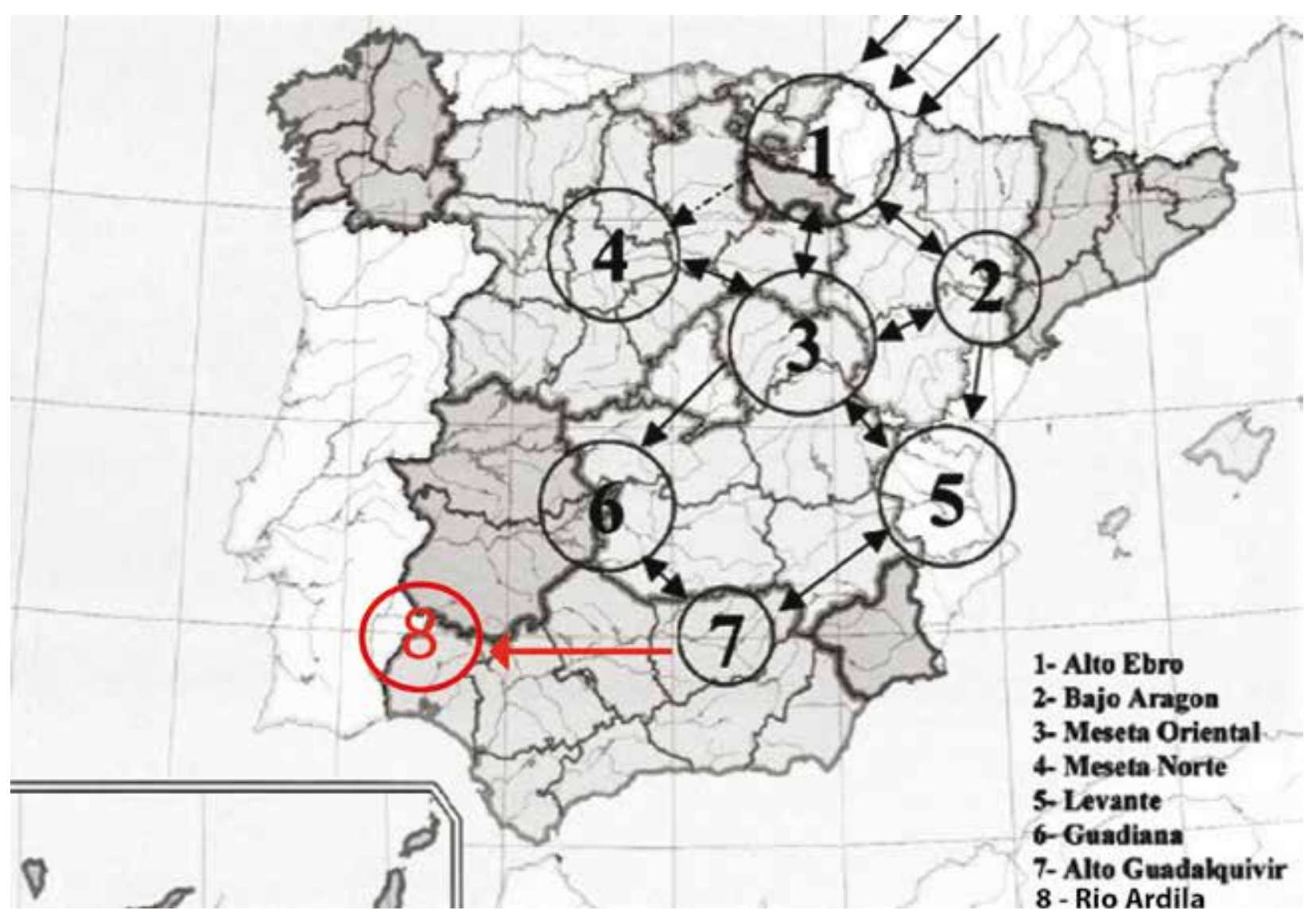

Figura 20 - Dispersão da decoração com grafite na P.I. (modificado a partir de Nájera Marcos, 2009, p. 80)

Todavia, a cerâmica grafitada permanece ainda uma decoração desconhecida para a maioria dos investigadores e as suas próprias características tornam-na alvo fácil de equívocos, facto que poderá conduzir a que o cenário aqui traçado venha a conhecer importantes alterações no futuro.

\section{BiBLIografíA}

Amo y de la Hera, M. del (1978), "El Castañuelo. Un poblado céltico en la provincia de Huelva", Huelva Arqueológica, 4, 299-340.

Antunes, A. (2005), Castro da Azougada - conjunto cerâmico. Em torno da Idade do Ferro Pós-Orientalizante da margem esquerda do Baixo Guadiana, Lisboa, Faculdade de Letras da Universidade de Lisboa, Tese de Mestrado, exemplar policopiado.

Antunes, A. (2009), Um conjunto cerâmico da Azougada: em torno da Idade do Ferro Pós-Orientalizante da margem esquerda do Baixo Guadiana, O Arqueólogo Português, Suplemento 5, Lisboa, Museu Nacional de Ar- queologia.

Barroso Bermejo, R. (2002), "Cuestiones sobre las cerámicas grafitadas del bronce Final y la I Edad del Hierro de la península Ibérica”, Trabajos de Prehistoria 59/1, 127-142.

Blazquéz Martínez, J. e Valiente Malla, J. (1980), "Cerámicas grafitadas del poblado de la Muela de Castulo (Linares, Jaen)", Trabajos de Prehistoria, 37, 399-418.

Blazquéz Martínez, J. e Valiente Malla, J. (1981), Castulo III, Madrid, Ministerio de Cultura.

Cardoso, J.e Soares, R. (2013), "Faunas Mamalógicas do Sítio Pós-Orientalizante do Cabeço Redondo (Sobral da Adiça, Moura). Escavações de 2011", Al-madan, II Série. 18, 87-92.

Celestino Pérez, S. -Ed.- (1996), El Palacio-Santuario de Cancho Roano V-VI-VII. Los sectores Oeste, Sur y Este, Junta de Extremadura, Badajoz.

Celestino Pérez, S. e Jiménez Ávila, J. (1993), El Palacio-Santuario de Cancho Roano I: El sector Norte, Junta de Extremadura, Badajoz. 
Costa, T. (2010), O Castelo Velho de Safara (Moura): Elementos para o seu estudo, Lisboa, Faculdade de Letras da Universidade de Lisboa, Tese de Mestrado, exemplar policopiado.

Ellering, S. W. (1987-1988), “Consideraciones sobre la cerámica con decoración grafitada de la Península Ibérica", Kalathos, 7-8, 185-194.

Jiménez Ávila, J. (2009), "El poblado de El Castañuelo (Aracena) y el PostOrientalizante en la Sierra Norte de Huelva”, Actas do IV Encuentro de Arqueología del Suroeste Peninsular (J.A. Pérez Macías y E. Romero Bomba, Eds.), Huelva, 3-33.

Jiménez Ávila, J. e Ortega Blanco, J. (2004), La cerámica griega en Extremadura, Cuadernos Emeritenses, 28, Mérida.

Langley, M., Mataloto, R., Boaventura, R. E Gonçalves, D. (2007), “A ocupação da Idade do Ferro de Torre de Palma: "Escavando nos fundos" do Museu Nacional de Arqueologia", O Arqueólogo Português, Série IV, 25, 229-290.

Macías, S. (1992), "Moura, um projecto de investigação em arqueologia medieval e moderna”, Penélope, 7, 127-134.

Mataloto, R. (2004), Um "monte" da Idade do Ferro na Herdade da Sapatoa - Ruralidade e povoamento no $1^{o}$ Milénio a. C. do Alentejo Central, Trabalhos de Arqueologia, 37, Instituto Português de Arqueologia, Lisboa.

Nabais, M. e Soares, R. (no prelo), Zooarchaeological evidence from the Iron Age site of Castro da Azougada (Moura, Portugal). Revista Portuguesa de Arqueologia.

Nájera Marcos, I. (2009), "La cerámica pintada al grafito en el alto Ebro", Saldvie, 9, 71-96.

Pérez Macías, J. (1991), Castañuelo. Los orígenes de la Baeturia Celtica, Cuaderno Temático, 1 , Museo de Huelva, Huelva.

Pérez Macías, J. e Gómez Toscano, F. (1999), "Cronología y significación histórica del poblado de Castañuelo (Aracena, Huelva)", II Congreso de Arqueología Peninsular (R. Balbín Berhmann e P. Bueno Ramirez, Eds.), Zamora, 467-476.

Rodríguez Díaz, A. -ed.- (2004), El edificio protohistórico de "La Mata" (Campanario, Badajoz) y su estudio territorial, Universidad de Extremadura, Cáceres.

Soares, A. M. (2001), "O Castelo Velho de Safara. Notícia preliminar”, Vipasca. 10, 57-64.

Soares, R. (2012), O Cabeço Redondo: um edifício da Idade do Ferro pós-orientalizante na Her- dade do Metum (Moura), Lisboa, Faculdade de Letras da Universidade de Lisboa, Tese de Mestrado, exemplar policopiado.

Soares, R. e Soares, A. M. (no prelo), “O Cabeço Redondo (Moura): um edifício monumental e singular na margem esquerda do Guadiana”, Sidereum Ana III, El Río Guadiana y Tartessos (Mérida, 19-21 de setiembre 2012).

Soares, R., Valério, P., Soares, A. e Araújo, M. de F. (2013), "Rodas de Oleiro no Pós-Orientalizante: primeiros achados em território português no Cabeço Redondo (Sobral da Adiça, Moura), Actas del VI Encuentro de Arqueología del Suroeste Peninsular (J. Jiménez Ávila, M. Bustamante Álvarez e M. García Cabezas, Miriam, Eds), Villafranca de los Barros, 1133-1155.

Valério, P., Silva, R., Soares, A., Araújo, M., Gonçalves, A. e Soares, R. (2015), "Combining X-ray based methods to study the protohistoric bronze technology in Western Iberia", Nuclear Instruments and Methods in Physics Research Section B: Beam Interactions with Materials and Atoms, V/358, 117-123

Valente, G. E Soares, R. (no prelo), "A Idade do Ferro no Castelo de Moura: resultados das sondagens para instalação do Posto de Recepção ao Turista”, IX Encontro de Arqueologia do Sudoeste peninsular. 
